\title{
Gut Metabolite Trimethylamine N-Oxide Protects INS-1 $\beta$-Cell and Rat Islet Function under Diabetic Glucolipotoxic Conditions
}

\author{
Emily S. Krueger ${ }^{1}{ }^{\circledR}$, Joseph L. Beales ${ }^{1,+}{ }^{\dagger}$, Kacie B. Russon ${ }^{1}$, Weston S. Elison ${ }^{1, \ddagger}{ }^{\circledR}$, Jordan R. Davis ${ }^{1}$, \\ Jackson M. Hansen ${ }^{2}$, Andrew P. Neilson ${ }^{3}{ }^{(0)}$, Jason M. Hansen ${ }^{2}$ and Jeffery $S$. Tessem ${ }^{1, * \mathbb{C}}$
}

1 Department of Nutrition, Dietetics, and Food Science, Brigham Young University, Provo, UT 84602, USA; emilys.krueger@gmail.com (E.S.K.); jlbeales@gmail.com (J.L.B.); kacie.russ@gmail.com (K.B.R.); weston.elison@gmail.com (W.S.E.); jordanricharddavis@gmail.com (J.R.D.)

2 Department of Cell Biology and Physiology, Brigham Young University, Provo, UT 84602, USA; Jacksonmhansen8@gmail.com (J.M.H.); jason_hansen@byu.edu (J.M.H.)

3 Plants for Human Health Institute, Department of Food, Bioprocessing and Nutrition Sciences, North Carolina State University, Kannapolis, NC 28081, USA; aneilso@ncsu.edu

* Correspondence: jeffery_tessem@byu.edu; Tel.: +1-801-422-9082

+ Current Affiliation: Medical Education Program, Paul L. Foster School of Medicine, El Paso, TX 79905, USA.

$\ddagger$ Current Affiliation: Biomedical Sciences Program, University of California San Diego, La Jolla, CA 92093, USA.

\section{check for} updates

Citation: Krueger, E.S.; Beales, J.L.; Russon, K.B.; Elison, W.S.; Davis, J.R.; Hansen, J.M.; Neilson, A.P.; Hansen, J.M.; Tessem, J.S. Gut Metabolite Trimethylamine N-Oxide Protects INS-1 $\beta$-Cell and Rat Islet Function under Diabetic Glucolipotoxic Conditions. Biomolecules 2021, 11, 1892. https://doi.org/10.3390/ biom 11121892

Academic Editor: Alberto Bartolomé

Received: 2 November 2021

Accepted: 14 December 2021

Published: 17 December 2021

Publisher's Note: MDPI stays neutral with regard to jurisdictional claims in published maps and institutional affiliations.

Copyright: (c) 2021 by the authors. Licensee MDPI, Basel, Switzerland. This article is an open access article distributed under the terms and conditions of the Creative Commons Attribution (CC BY) license (https:/ / creativecommons.org/licenses/by/ $4.0 /)$.

\begin{abstract}
Serum accumulation of the gut microbial metabolite trimethylamine N-oxide (TMAO) is associated with high caloric intake and type 2 diabetes (T2D). Impaired pancreatic $\beta$-cell function is a hallmark of diet-induced T2D, which is linked to hyperglycemia and hyperlipidemia. While TMAO production via the gut microbiome-liver axis is well defined, its molecular effects on metabolic tissues are unclear, since studies in various tissues show deleterious and beneficial TMAO effects. We investigated the molecular effects of TMAO on functional $\beta$-cell mass. We hypothesized that TMAO may damage functional $\beta$-cell mass by inhibiting $\beta$-cell viability, survival, proliferation, or function to promote T2D pathogenesis. We treated INS-1 832/13 $\beta$-cells and primary rat islets with physiological TMAO concentrations and compared functional $\beta$-cell mass under healthy standard cell culture (SCC) and T2D-like glucolipotoxic (GLT) conditions. GLT significantly impeded $\beta$-cell mass and function by inducing oxidative and endoplasmic reticulum (ER) stress. TMAO normalized GLT-mediated damage in $\beta$-cells and primary islet function. Acute $40 \mu \mathrm{M}$ TMAO recovered insulin production, insulin granule formation, and insulin secretion by upregulating the IRE1 $\alpha$ unfolded protein response to GLT-induced ER and oxidative stress. These novel results demonstrate that TMAO protects $\beta$-cell function and suggest that TMAO may play a beneficial molecular role in diet-induced T2D conditions.
\end{abstract}

Keywords: beta cell; islet; glucolipotoxicity (GLT); glucose stimulated insulin secretion (GSIS); unfolded protein response (UPR); type 2 diabetes (T2D)

\section{Introduction}

High caloric intake from a Western diet rich in animal proteins and fats is linked to chronic cardiovascular and metabolic diseases, including cardiovascular disease (CVD) and type 2 diabetes (T2D), which drive global mortality and morbidity rates [1-7]. This diet can include high levels of quaternary amine-containing semi-essential nutrients, such as choline and carnitine, and the concomitant gut microbial metabolites are associated with pathogenic mechanisms [8-11]. Dietary excess of these nutrients is metabolized by the gut microbiome to trimethylamine prior to absorption [12-15]. At the liver, trimethylamine is oxidized by flavin-containing monooxygenase 3 (FMO3) to trimethylamine N-oxide 
(TMAO), which travels through the circulation and is eliminated in the urine. TMAO produced by this gut microbiome-liver axis can accumulate in the circulation and is a known chronic disease biomarker and proposed aggravator of CVD [9,13,16-18].

Metabolomic studies originally linked elevated serum TMAO levels to CVD through atherosclerotic mechanisms [8,19-22]. Although elevated TMAO has since been associated with other diet-mediated metabolic diseases, the direct molecular TMAO effects in the relevant tissues are unclear $[6,21,23-28]$. Some studies report that $7 \mu \mathrm{M}$ to $1 \mathrm{M}$ concentrations of TMAO may beneficially reduce cellular stress $[9,23,29-35]$. However, in obese T2D patients, elevated TMAO is associated with hyperglycemia, hyperlipidemia, and insulin resistance [4-7].

Within the pancreas, islets of Langerhans contain metabolic hormone-secreting cells, including $\beta$-cells, which secret insulin to manage blood glucose levels [36-38]. Healthy $\beta$-cell function is characterized by the proper sensing of elevated blood glucose via GLUT2, a low-affinity glucose transporter, and glucokinase [39-41]. The resulting signals from complete glucose metabolism through glycolysis, the tricarboxylic acid (TCA) cycle, and oxidative phosphorylation induce insulin production and secretion [41]. $\beta$-cells are highly susceptible to metabolic cellular stresses, which contribute to the T2D condition [42-44]. In patients consuming a Western diet, hyperglycemia and hyperlipidemia reduce functional $\beta$-cell mass to drive T2D progression [41,45-53]. Therefore, to elucidate the role of TMAO in T2D pathogenesis, understanding its effects on functional $\beta$-cell mass is imperative [54]. This study is the first to culture INS-1 832/13 $\beta$-cells and primary rat islets with physiological TMAO concentrations under healthy standard cell culture (SCC) or T2D-like glucolipotoxic (GLT) conditions. Since TMAO is more commonly proposed as an aggravator of chronic diseases, we hypothesized that it would reduce functional $\beta$-cell mass under SCC and worsen the T2D phenotype under GLT conditions.

\section{Materials and Methods}

\subsection{Cell and Tissue Culture}

The rat insulinoma INS-1 832/13 $\beta$-cell line was maintained in standard culture media containing RPMI 1640 + L-glutamine (Corning, Corning, NY, USA, 50-020-PB) combined with 10\% fetal bovine serum (MilliporeSigma, Burlington, MA, USA, C948C69), 50ug/mL streptomycin and $50 \mathrm{U} / \mathrm{mL}$ penicillin (LONZA, Basel, Switzerland, 17-745E), 10mM HEPES (ThermoFisher, Waltham, MA, USA, 15630080), and INS-1 832/13 supplement, as described previously $[55,56]$. Passage doublings under 100 were seeded to culture plates (VWR, Radnor, PA, USA, 10861-698, 10861-700, 10861-702, 10861-666) (biological triplicates) at approximately 105,000 cells $/ \mathrm{mL}$ or 40,000 cells $/ \mathrm{cm}^{2}$ and acclimated to standard incubation overnight prior to treatment for experimental assays.

Adult wildtype Wistar rats (Charles River, Wilmington, MA, USA) were maintained under standard housing, feeding (LabDiet, St. Louis, MO, USA, Rodent 5001), and husbandry protocols. Four 3-month-old females (biological replicates) were euthanized by $\mathrm{CO}_{2}$, and primary islets were isolated by collagenase digestion and handpicked into standard media as described previously [57-59]. After $2 \mathrm{~h}$ of acclimation, groups of 35 islets from each animal were randomly handpicked into TMAO treatments in SCC or GLT cultures for $24 \mathrm{~h}$. All animal work was approved by the Brigham Young University (BYU) Animal Committee and complied with the National Research Council's Guidelines for the Care and Use of Laboratory Animals (IACUC Protocol Number 19-1002) and the ARRIVE guidelines. Protocol details are available as needed and upon request.

\subsection{Experimental Culture Treatments}

For SCC studies, standard culture medium was replaced with medium containing TMAO (MilliporeSigma, Burlington, MA, USA, 1184-78-7). For GLT studies, TMAO treatments were combined in GLT media containing three additional components, including $25 \mathrm{mM}$ glucose (MilliporeSigma, 50-997), 0.5mM palmitate (TCI, 408-35-5), and bovine serum albumen ( $0.67 \%$ final concentration) (ThomasScientific, C974Z33). To in- 
corporate the palmitate in the aqueous environment of the medium, we dissolved it in 1:1 ethanol and water and conjugated it to the albumen as described previously [60,61]. Such GLT cultures were established to model diet-driven T2D pathogenesis [51,52,62-66]. TMAO was dissolved in water and diluted serially for total culture concentrations between 0.3 and $160 \mu \mathrm{M}$, which reflects clinical levels [16,20,67-74]. This range of clinical serum TAMO levels is dependent on the method of analysis, the subject's diet, and the disease state. T2D, Metabolic Syndrome, and CVD are predicted by serum TMAO levels over 7 or $8 \mu \mathrm{M}[27,75-78]$. At the most extreme, serum TMAO can increase to $170 \mu \mathrm{M}$ in patients with various chronic diseases $[5,25,68,70,72,74,75,79-86]$. T2D or CVD patients present levels at or above $20 \mu \mathrm{M}[5,25,68,70,72,74,75,79-86]$. Alternatively, healthy patients present low levels from 1 to $3 \mu \mathrm{M}[8,16,67,87-89]$. Therefore, to represent these variable clinical TMAO concentrations, we investigated the 0.3 and $160 \mu \mathrm{M}$ range of TMAO in both the SCC and GLT conditions. Since TMAO accumulates after a single meal containing precursor nutrients and remains elevated for the duration of the diet $[13,16,87,90,91]$, our proof of concept studies used $24 \mathrm{~h}$ treatments (Figure S1A,B). Although we investigated the independent $\beta$-cell function and proliferation effects of the individual components of the GLT model, we found that the combined mixture of all the GLT components was most sufficient to model the T2D $\beta$-cell phenotype. In both the SCC and GLT experiments, no TMAO treatment (NT) controls were used as references on each of the 3 experimental cultures (biological triplicates).

\subsection{Tetrazolium Salt MTT Viability Assay}

After experimental culture, treatment media was replaced with media containing 3-(4,5-dimethylthiazol-2-yl)-2,5-diphenyl tetrazolium bromide (MTT) (CHEMIMPEX, 00697) dissolved in phosphate-buffered saline (PBS) and incubated for $4 \mathrm{~h}$, as described previously [92]. Healthy mitochondrial NADH dependent dehydrogenase or superoxide dismutase reduced MTT to form tetrazolium salts and indicate cell viability [62,92-94]. Tetrazolium salts formed by viable cells were solubilized with acid-isopropanol, and absorbance was measured with the BioTek Synergy 2 plate reader at $570 \mathrm{~nm}$, with a reference wavelength of $600 \mathrm{~nm}$. The mitochondrial viability measurements of 4 culture plate wells (technical replicates) were normalized to the associated SCC NT controls and averaged per culture (biological triplicates).

\subsection{Annexin $V(A V)$ and 7-Aminoactinomycin D (7-AAD) Survival Assay}

At harvest, adherent and floating $\beta$-cells were collected and stained with $A V$, which binds phosphatidylserine on the outer leaflet of the cell membrane during early apoptosis and 7-AAD, which intercalates with the DNA of dead and dying cells (BD Pharmingen Apoptosis Kit, 559763). Stained samples were analyzed with the Accuri C6 Plus Flow Cytometer, and cell population gaits were assigned using unstained and single stained controls. After selecting the singlet data events, unstained cells were designated as healthy, while AV positive, 7-AAD positive, and double-positive populations were aggregated to represent dead and dying cells (Figure S2). Identical compensation and gating were applied to all experimental samples, and the resulting quadrant percentages were analyzed. The percent healthy and the percent dying values of 3 culture plate wells (technical triplicates) were averaged per culture (biological triplicates).

\section{5. [3H]-Thymidine Incorporation Proliferation Assay}

To measure $\beta$-cell proliferation rates, treatment medium was replaced with medium containing radiolabeled [methyl-3H]-thymidine (PerkinElmer, Waltham, MA, USA, NET027E001MC), as described previously [95]. DNA was precipitated with $10 \%$ trichloroacetic acid and solubilized with $0.3 \mathrm{M} \mathrm{NaOH}$, and incorporation was measured by liquid scintillation counting. Counts per minute were normalized to total protein measured by the bicinchoninic acid assay (BCA) (ThermoFisher Scientific, Waltham, MA, USA, 23225). These 
proliferation values of 4 culture plate wells (technical replicates) were normalized to the associated SCC NT controls and averaged per culture (biological triplicates).

\subsection{Glucose-Simulated Insulin Secretion (GSIS) Assay}

At harvest, $\beta$-cell and islet treatment medium was replaced with secretion assay buffer containing $2.8 \mathrm{mM}$ followed by $12 \mathrm{mM}$ glucose, as described previously [55,96]. TMAO treatment concentrations were maintained in the buffer during static stimulation incubations. Cells were lysed, and insulin concentration in secretion samples and lysate were measured by enzyme-linked immunosorbent assay, as described previously [97]. Insulin standards were purchased separately (Monobind Inc., Lake Forest, CA, USA, 2425-300) and used to quantify these sample concentrations. Insulin measurements were normalized by total protein measured by the BCA. These insulin values of 4 culture plate wells (technical replicates) were normalized to the associated SCC NT controls and averaged per culture (biological triplicates).

\subsection{Scanning Transmission Electron Microscopy (STEM)}

For STEM imaging, INS-1 $\beta$-cells were seeded to coverslips, and groups of three coverslips were cultured with treatments as described in Section 2.2 (biological triplicates). At harvest, cells were fixed, stained, sectioned, and imaged on a scanning electron microscope in STEM mode at the BYU Electron Microscopy Facility. Cytosol area and granule counts were manually quantified using ImageJ, as described previously $[54,98,99]$. The number of mature and immature insulin granules per total cytosolic area was quantified for each image. We averaged counts for three images (technical triplicates) per culture, yielding 9 total images analyzed per experimental treatment. Values were not normalized to report untransformed values.

\subsection{Glutathione (GSH) Assay}

After experimental culture, $\beta$-cells were lysed, and concentrations of GSH and glutathione disulfide (GSSG) were determined via high performance liquid chromatography, as described previously $[100,101]$. Concentrations were measured as S-carbosymethyl, $\mathrm{N}$-dansyl derivatives using an internal standard for quantification, and values were corrected by total protein and were expressed as nmol GSH/mg protein [102]. Redox potentials (Eh) were determined via the Nernst equation, as described previously [103]. Quantification of the S-glutathionylation of proteins (Pr-SSG) was determined by the reduction of modified proteins, as described previously [104]. In short, harvested protein pellets were re-solubilized in buffer containing dithiotrheitol to remove GSH from Pr-SSG before derivatization for HPLC analysis. These measurements of 3 culture plate wells (technical replicates) were averaged per culture (biological triplicates).

\section{9. $q P C R$}

For qPCR, $\beta$-cells were lysed, and mRNA was harvested as previously described [105]. qPCR was performed using the Life Technologies Quant Studio 6 Detection System and Software (Thermo Fisher), using SYBR green primers and qPCR master mix (Bio-Rad, Hercules, CA, USA), as previously described [105] for Total XBP1, sXBP1, and PPIA. Relative mRNA levels for Total XBP1 and sXBP1 were calculated using the Delta CT method, with PPIA being used as a housekeeping gene. Sequences are available upon request.

\subsection{Western Blots}

For Western blots, $\beta$-cells were lysed, and blotting, transfers, and imaging (LI-COR Biotechnology) were performed as described previously [55]. Protein concentration was determined by BCA, and samples were loaded in the gel at $25 \mu \mathrm{g} / \mathrm{lane}$. Blots were probed for inositol-requiring enzyme $1 \alpha$ (IRE1 $\alpha$ ) (Cell Signaling, Danvers, MA, USA, 3294, 1:1000), PRKR-like Endoplasmic reticulum kinase (PERK) (Cell Signaling, 3192, 1:1000), phosphor-PERK (Cell Signaling, 3179, 1:1000), ATF4 (GeneTex, Irvine, CA, USA, 
GTX101943, 1:1000), and X-box bind protein 1 (XBP1) (GeneTex, GTX102229, 1:1000), and Tubulin (Proteintech, Rosemont, IL, USA, 66031-1-Ig, 1:25,000) as a loading control. These expression measurements of 3 culture plate wells (technical replicates) were normalized to the associated SCC NT controls and averaged per culture (biological triplicates).

\subsection{Statistical Analysis}

Data presented in the text represent mean percent change between SCC NT and GLT NT controls. As indicated in each experimental method and figure legend, the mean of 3 to 4 technical replicates constituted the measurements of 3 to 4 predetermined biological replicates $(n=3$ or 4$)$, with error bars indicating the standard error. For INS- $1 \beta$-cell cultures, each independent culture plate, and for primary islet cultures, each independent animal, was considered a biological replicate. Statistical analyses were performed with GraphPad Prism 9, where $p<0.05$ was considered significant, but instances of $p<0.1$ were also reported. Statistical comparisons included the normality test using the Shapiro Wilk test, one-way ANOVA with Tukey's post hoc test, and two-way ANOVA with Šidák's post hoc test, as indicated in the figure legends.

\section{Results}

\subsection{TMAO Does Not Alter GLT-Mediated Reduction of $\beta$-Cell Mass}

Since impaired functional $\beta$-cell mass is a hallmark of T2D pathogenesis, we explored the viability, survival, and proliferation rates of TMAO-treated $\beta$-cells in SCC and GLT conditions (Figure 1). Mitochondrial viability assays showed that $160 \mu \mathrm{M}$ TMAO was cytotoxic under SCC conditions (Figure 1A), and GLT reduced mitochondrial viability by $31 \%$ (Figure 1B). Since this assay reports mitochondrial viability as a surrogate for cell mass, we investigated $\beta$-cell survival via dead and dying cellular markers AV and 7-AAD. There was minimal cell death and no significant TMAO effect in SCC studies (Figure 1C), while GLT increased the dead and dying population by $38 \%$ (Figure 1D). Finally, we measured $\beta$-cell proliferation by quantifying DNA synthesis rates where TMAO showed no effect (Figure 1E,F). While GLT did significantly reduce total protein concentration during the $\left[{ }^{3} \mathrm{H}\right]$-thymidine assay, when DNA synthesis rates were corrected by these values, the comparisons were not significant (Figure S1C-E). Together, these data illustrate that while GLT reduces $\beta$-cell mass by decreasing mitochondrial viability and increasing cell death, TMAO does not alter $\beta$-cell mass.

\subsection{TMAO Normalizes GLT-Damaged $\beta$-Cell and Islet Function}

To investigate TMAO effects on $\beta$-cell function, we performed GSIS assays to measure the insulin secretion and production capacity of $\beta$-cells treated with TMAO under SCC and GLT conditions (Figure 2A-D). SCC only controls secreted 4.4-fold more insulin during $12 \mathrm{mM}$ high glucose stimulation compared to the $2.8 \mathrm{mM}$ low glucose stimulation (Figure 2A,C). This significant difference between the low and high glucose insulin secretion values indicates healthy glucose sensing, which is hindered by GLT (Figure 2C). GSIS was worsened by $80 \mu \mathrm{M}$ TMAO in the SCC condition (Figure 2A), while 20 and especially $40 \mu \mathrm{M}$ TMAO improved GLT-blunted GSIS (Figure 2C). To explore $\beta$-cell insulin production, we measured total insulin content (Figure 2D). TMAO did not significantly change insulin content in SCC treated cells (Figure 2B), but 20 and $40 \mu \mathrm{M}$ TMAO in the GLT condition recovered insulin content to healthy levels (Figure 2D). These results demonstrate a beneficial phenotype, where physiological concentrations of TMAO maintained $\beta$-cell insulin secretion and content during the damaging T2D-like GLT condition. 


\section{INS-1 $\beta$-cell Tetrazolium Salt MTT Assay}
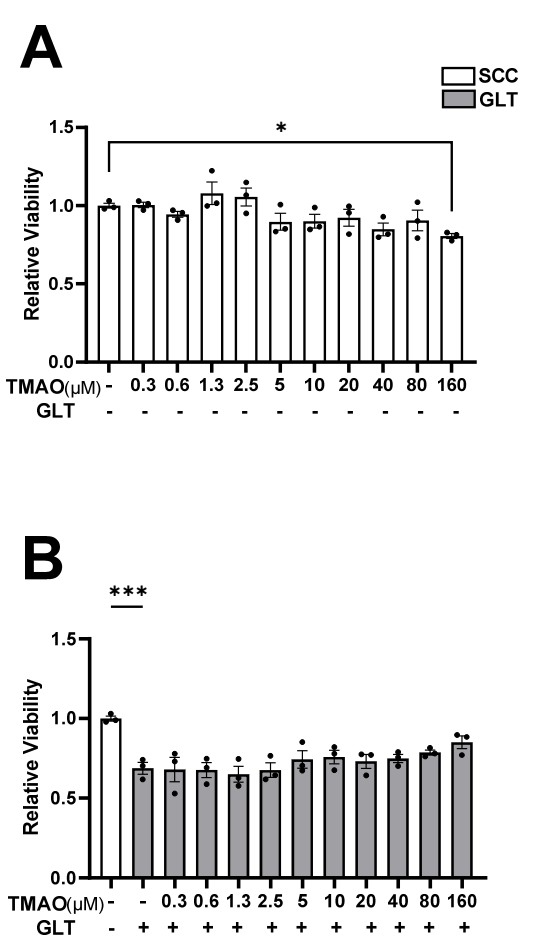
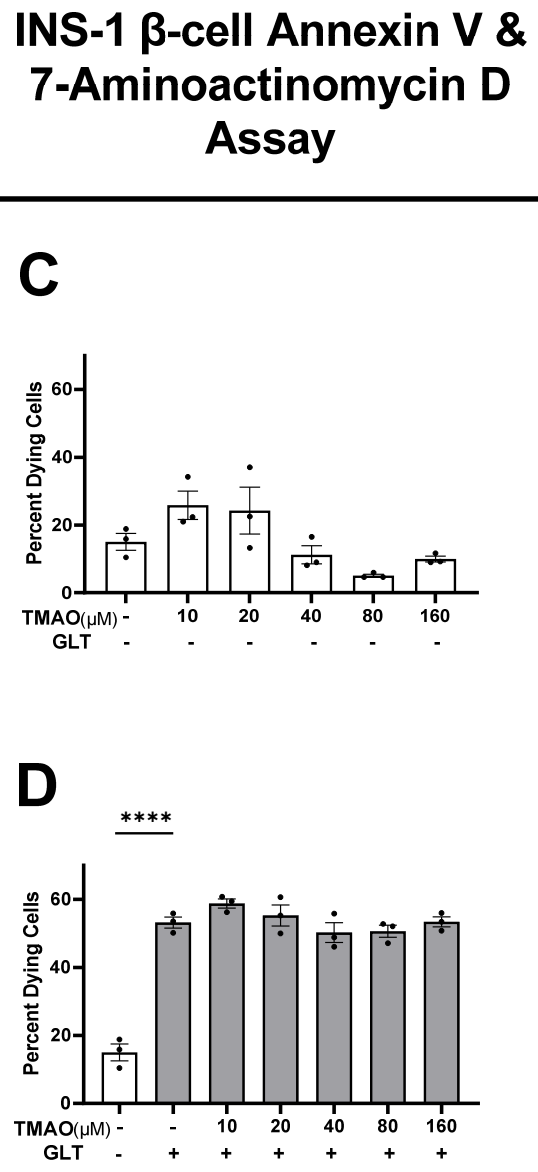

INS-1 $\beta$-cell $\left[{ }^{3} \mathrm{H}\right]-$ Thymidine Incorporation Assay

E
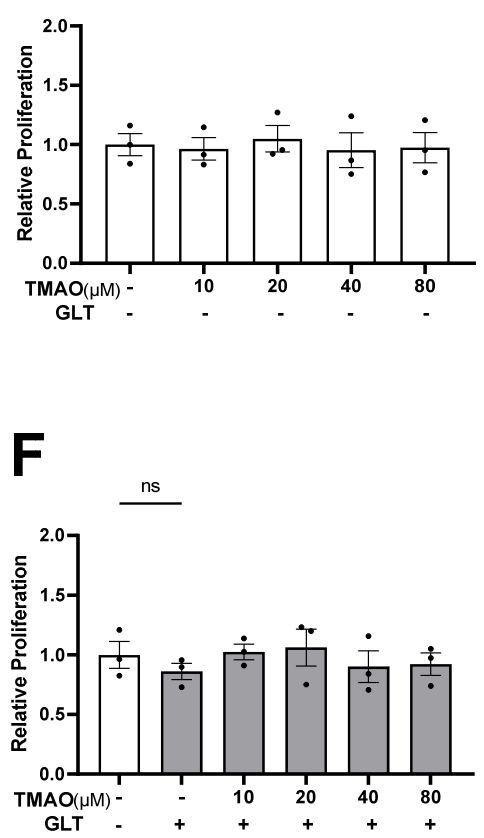

Figure 1. Trimethylamine N-oxide (TMAO) does not alter glucolipotoxicity (GLT)-mediated reduction of INS-1 $\beta$-cell mass. (A) Tetrazolium salt MTT measured mitochondrial viability of INS-1 $\beta$-cells cultured with or without TMAO for $24 \mathrm{~h}$ in standard cell culture (SCC), and (B) in GLT. (C) Flow cytometric measurement of dead and dying $\beta$-cell populations as measured by Annexin V and 7-aminoactinomycin D staining of $\beta$-cells cultured with or without TMAO for $24 \mathrm{~h}$ in SCC, and (D) in GLT. (E) $\beta$-cell proliferation measured by [3H]-thymidine incorporation of $\beta$-cells cultured with or without TMAO for $24 \mathrm{~h}$ in SCC, and (F) in GLT. (A,B,E,F) Values are normalized to SCC no treatment (NT) controls and (C,D) values reported as percent. (E,F) Proliferation data were normalized to cell protein content. All values represent the mean of biological triplicates $(\mathrm{n}=3)$. Error bars indicate the standard error. ${ }^{*}$ Indicates significant one-way ANOVA showing GLT and TMAO effects with $p$-values $*<0.05,{ }^{* * *}<0.001, * * * *<0.0001$, or not significant (ns).

Primary rat islet studies validate this beneficial TMAO phenotype (Figure 2E-H). Female mice are a common model in TMAO studies because their increased FMO3 expression and activity produces four-fold more TMAO than males [28]. However, because adult humans show a less pronounced sexual dimorphism in TMAO accumulation, we cultured adult female rat islets as a more relevant model [28,106-108]. As with $\beta$-cells, islet insulin section was inhibited by $80 \mu \mathrm{M}$ TMAO in SCC, while insulin content was unaffected (Figure 1E,F). Acute $40 \mu \mathrm{M}$ TMAO improved GSIS and insulin content levels in GLT cultured $\beta$-cells (Figure 2G,H). These islet data corroborated the $\beta$-cell results that $40 \mu \mathrm{M}$ TMAO is sufficient to normalize $\beta$-cell function impeded by GLT. While GSIS function is known to be dependent on mitochondrial function, we did not observe matching TMAO effects in the mitochondrial viability of $40 \mu \mathrm{M}$ TMAO treated GLT cultured $\beta$-cells (Figure 1B). Therefore we hypothesize that the increased insulin secretion observed here (Figure 2C,G) may be due to an increase in insulin production, as indirectly measured by the insulin content values (Figure 2D,H). 


\section{INS-1 $\beta$-cell Glucose Stimulated Insulin Secretion Assay}
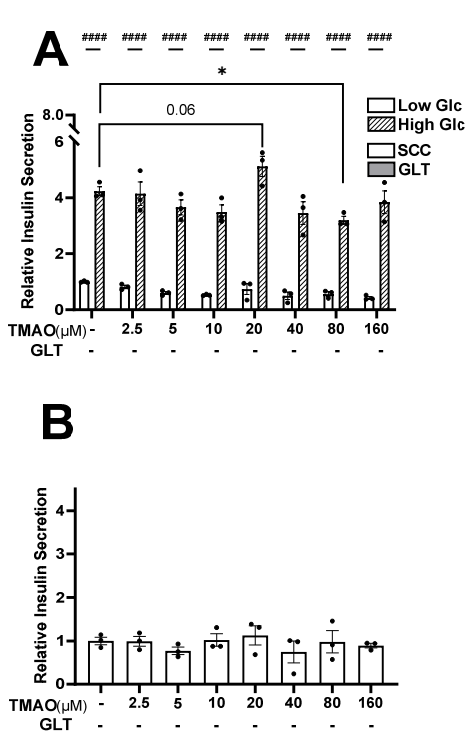

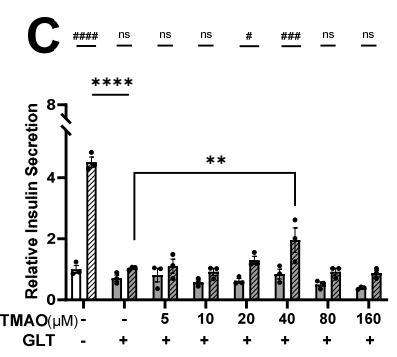

D

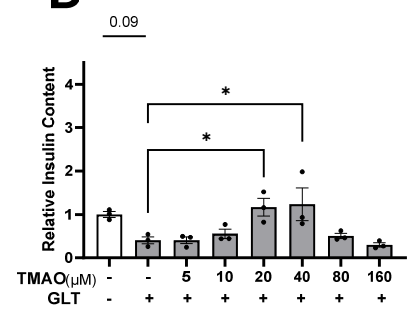

\section{Primary Rat Islet Glucose Stimulated Insulin Secretion Assay}
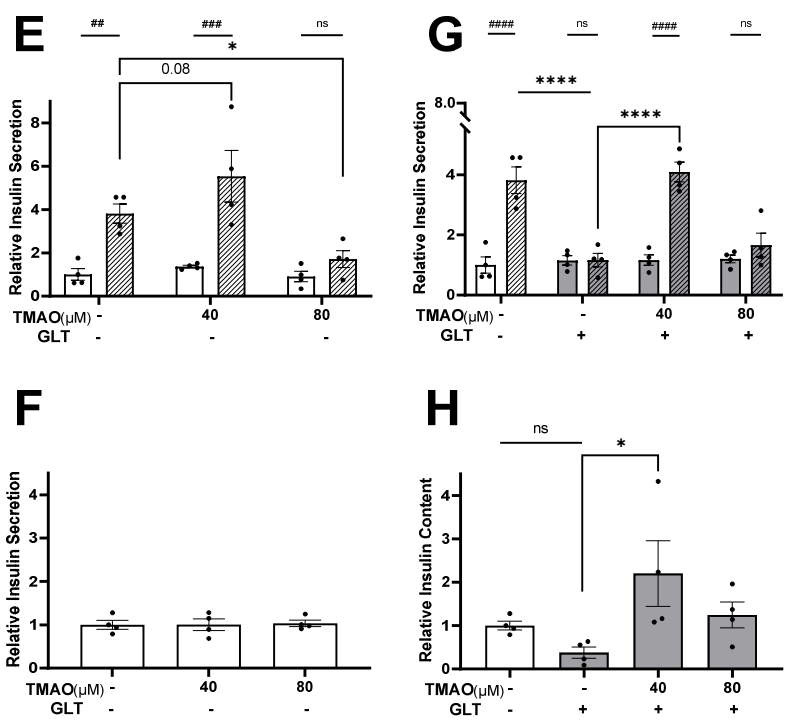

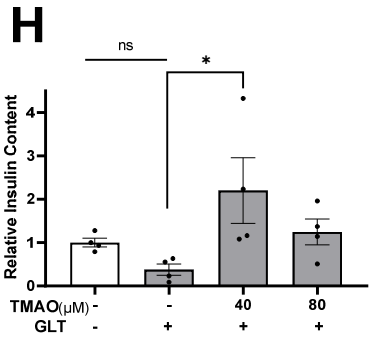

Figure 2. TMAO normalizes GLT-damaged INS-1 $\beta$-cells and primary rat islet function. (A) Insulin secretion under low (solid bars) vs. high glucose (striped bars) for INS-1 $\beta$-cells cultured with or without TMAO for $24 \mathrm{~h}$ in SCC condition, and (B) corresponding insulin content. (C) Insulin secretion from $\beta$-cells cultured with or without TMAO for $24 \mathrm{~h}$ in GLT condition, and (D) corresponding insulin content. (E) Insulin secretion from primary rat islets cultured with or without TMAO for $24 \mathrm{~h}$ in SCC, and (F) corresponding insulin content. (G) Insulin secretion from islets cultured with or without TMAO for $24 \mathrm{~h}$ in GLT, and (H) corresponding insulin content. All values are normalized to SCC NT controls and represent the mean of biological replicates $(\mathrm{n}=3$ or 4$)$. $(\mathbf{A}, \mathbf{C}, \mathbf{E}, \mathbf{D})$ \# Indicates significant paired two-way ANOVA comparing low vs. high glucose. (A-H) Error bars indicate the standard error. * Indicates significant one-way ANOVA showing GLT and TMAO effects, where $p$-values $<0.1$ given, ${ }^{*}<0.05,{ }^{* *}<0.01,{ }^{* * * *}<0.0001$, or ns.

\subsection{TMAO Recovers the Decrease in Insulin Granule Number Induced by GLT}

To more directly explore the TMAO effects on insulin production, we used STEM imaging to visualize $\beta$-cell insulin granule formation (Figure 3A). GLT reduced granule number per cell by $53 \%$ (Figure 3B). While TMAO did not alter granule numbers in SCC, in the GLT condition $40 \mu \mathrm{M}$ TMAO was sufficient to recover granule counts to healthy levels (Figure 3B). Therefore, TMAO presumably facilitates proper insulin production by maintaining mature granule formation despite deleterious GLT damage.

\subsection{TMAO Does Not Alter GLT-Mediated Changes to GSH or Redox Potential}

GLT is associated with increased reactive oxygen species (ROS) levels causing endoplasmic reticulum (ER) stress and mitochondrial dysfunction, which damage $\beta$-cell function [109-115]. $\beta$-cells are vulnerable to oxidative stress due to their limited endogenous antioxidant defense system, and reducing ROS levels is sufficient to recover healthy function $[43,44,47,113,116-118]$. Therefore, we investigated TMAO effects on the endogenous antioxidant GSH (Figure 4). GLT altered the redox potential (Figure 4C) of the $\beta$-cells by decreasing the GSH concentration by $47 \%$ (Figure $4 \mathrm{~A}$ ), without significantly affecting the GSSG (Figure 4B) or Pr-SSG concentrations (Figure 4D). It was shown that $40 \mu \mathrm{M}$ TMAO had no protective effects against these changes and that the beneficial TMAO phenotype we observed is not linked to alleviating oxidative stress caused by GLT. 


\section{INS-1 $\beta$-cell Scanning Transmission Electron Microscopy Imaging}

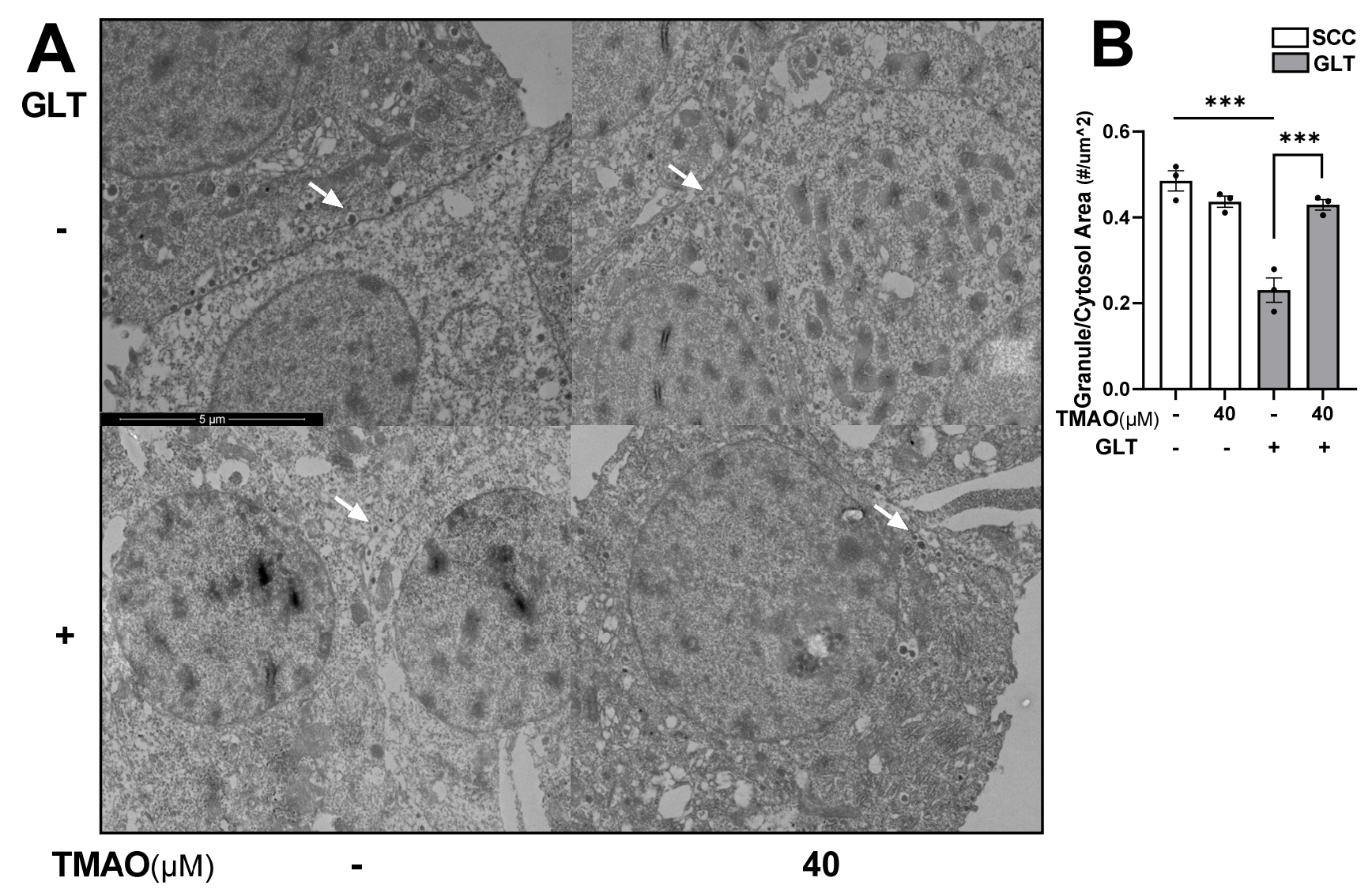

Figure 3. TMAO recovers the decrease in INS-1 $\beta$-cell insulin granule number induced by GLT. (A) Representative scanning transmission electron microscopy images of INS-1 $\beta$-cells cultured with or without $40 \mu \mathrm{M}$ TMAO for $24 \mathrm{~h}$ in SCC and GLT. White arrows identify examples of insulin granules. (B) Quantification of insulin granules/cytosol area. All values represent the mean of biological triplicates $(n=3)$. Error bars indicate the standard error. * Indicates significant one-way ANOVA showing GLT and TMAO effects, where $p$-values ${ }^{* *}<0.001$.

\subsection{TMAO Normalizes GLT Mediated Changes to Unfolded Protein Response (UPR) Components}

Insulin production begins with translation of the insulin mRNA at the rough ER before it is matured and packaged into granules. Therefore, ER stress triggered by unfolded protein accumulation during glucolipotoxicity is highly relevant to T2D $\beta$-cell dysfunction. We investigated TMAO effects on two arms of the UPR pathway (Figure 5). GLT slightly induced p-PERK expression, which resulted in a $77 \%$ reduction by $40 \mu \mathrm{M}$ TMAO, indicating that TMAO reversed the GLT-mediated ER stress (Figure 5A,B). Interestingly, total PERK levels were significantly upregulated by TMAO treatment under GLT conditions (Figure 5A,C). While TMAO reduced p-PERK levels under GLT, it did not affect its downstream target, ATF4, which was elevated under GLT conditions (Figure 5D,E). Since ATF4 signals apoptosis, this non-significant result corresponds with the previous $\beta$-cell survival data (Figure 1D). In the second arm of the UPR, GLT reduced IRE1 $\alpha$ expression by $83 \%$, which was normalized by TMAO (Figure 5F,G). IRE1 $\alpha$ splices the XBP1 mRNA to yield two populations of XBP1 proteins. Measurements of total and spliced XBP1 (sXBP1) demonstrated that GLT resulted in similar induction of sXBP1 mRNA (Figure 5H,I). Western blotting demonstrated that under SCC and GLT conditions, TMAO reduced spliced $\mathrm{XBP} 1$ relative to the unspliced population ( $\mathrm{UXBP} 1)$ and relative to the tubulin control (Figure 5J-L). However, since changes in this protein were not observed in the GLT independent of TMAO, these minimal changes may not be physiologically meaningful. 
These data demonstrate that GLT induces ER stress and diminishes the IRE1 $\alpha$ UPR, which $40 \mu \mathrm{M}$ TMAO recovers to healthy levels. Therefore, taken together, our results suggest that $40 \mu \mathrm{M}$ TMAO is sufficient to normalize GLT-damaged insulin secretion and production by maintaining granule formation and recovering the IRE $1 \alpha$ UPR in INS- $1 \beta$-cells.

\section{INS-1 $\beta$-cell \\ Glutathione Assay}
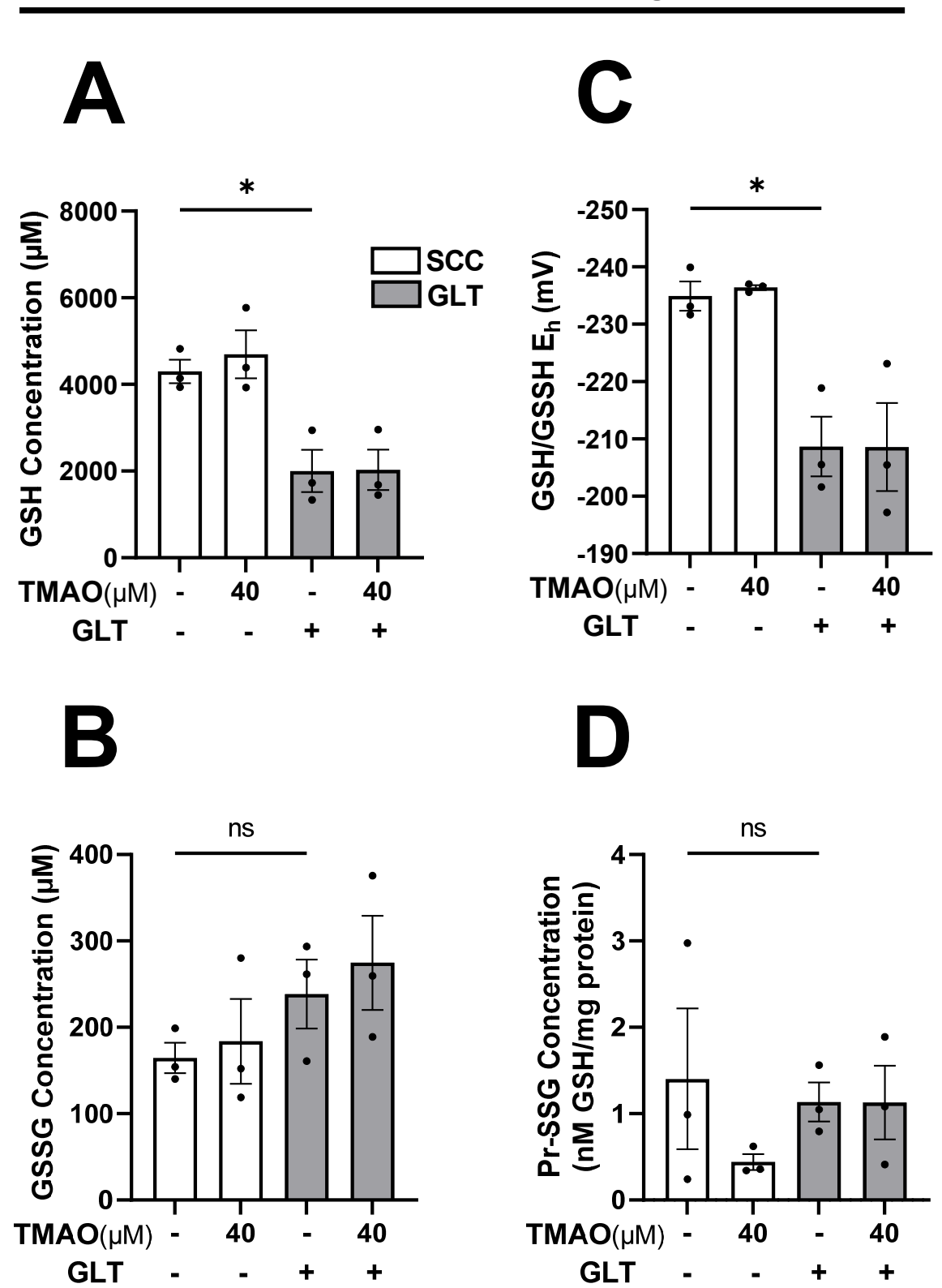

Figure 4. TMAO does not alter GLT-mediated changes to GSH or redox potential in INS-1 $\beta$-cells. INS-1 $\beta$-cells cultured with or without $40 \mu \mathrm{M}$ TMAO for $24 \mathrm{~h}$ in SCC and GLT were measured for (A) Glutathione (GSH) concentration, (B) Glutathione disulfide (GSSG) concentration, (C) GSH/GSSG redox state, and (D) Protein S-glutathionylation (Pr-SSG) concentration. All values represent the mean of biological triplicates $(n=3)$. Error bars indicate the standard error. ${ }^{*}$ Indicates significant one-way ANOVA showing GLT effects, where $p$-values * $<0.05$ or ns. 
INS-1 $\beta$-cell Unfolded Protein Responce Western Blots and qPCR

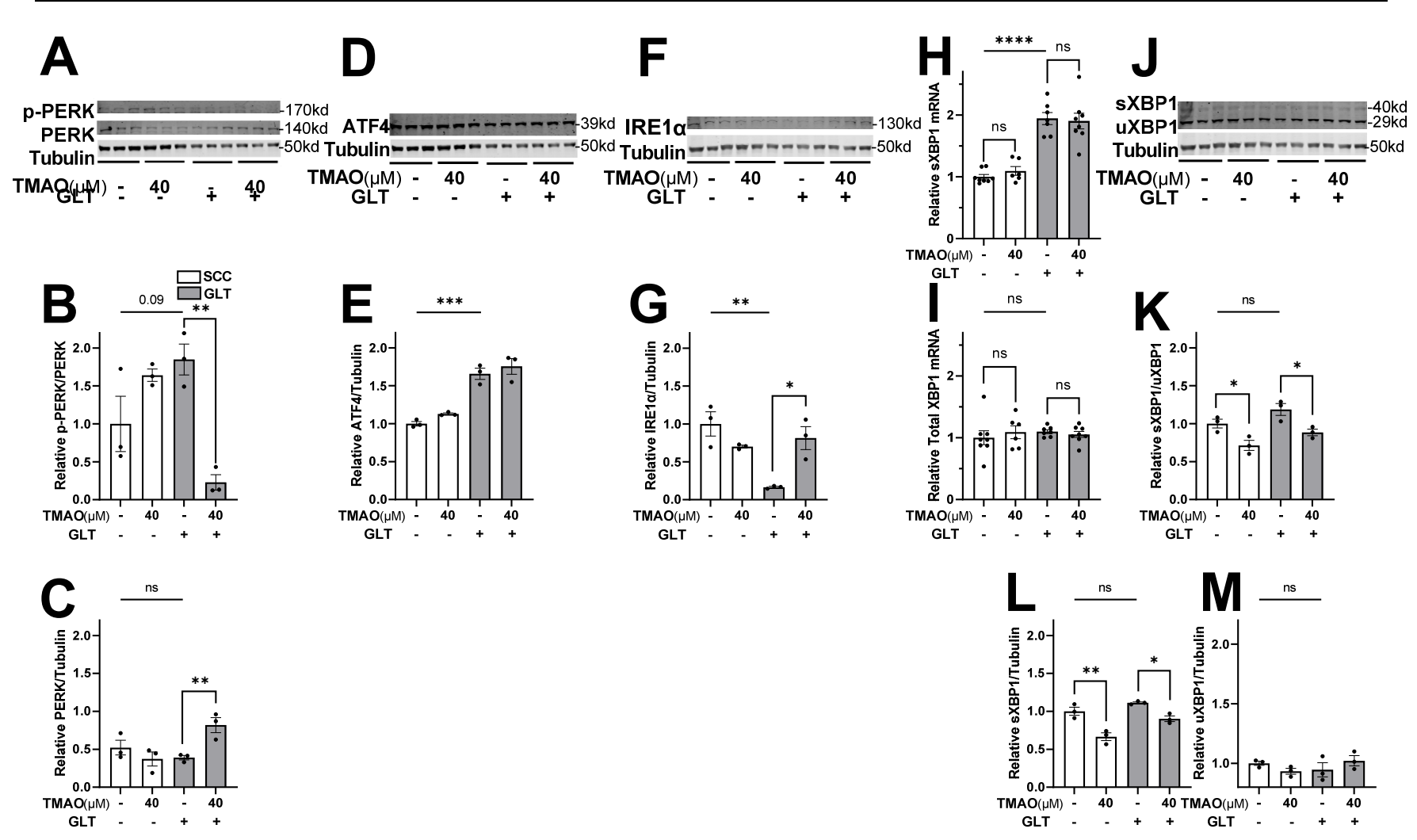

Figure 5. TMAO normalizes GLT-mediated reduction of the IRE1 $\alpha$ unfolded protein response (UPR) in INS- $1 \beta$-cells. INS-1 $\beta$-cells cultured with or without $40 \mu \mathrm{M}$ TMAO for 24 in SCC and GLT were measured for changes to UPR pathway proteins by Western blotting and mRNA by qPCR. Samples were probed and quantified for p-PERK (170kd) and PERK (140kd) (A-C), ATF4 (39kd) (D,E), IRE1 $\alpha$ (130kd) (F,G), sXBP1 (40kd) and uXBP1 (29kd) (J-M). mRNA of sXBP1 and total XBP1 were measured by qPCR (H,I). Abbreviations: quantitative polymerase chain reaction (qPCR), phospho-protein kinase RNA-like ER kinase (p-PERK), activating transcription factor (ATF4), inositol-requiring enzyme $1 \alpha($ IRE1 $\alpha)(\mathbf{A}, \mathbf{B})$, spliced and unspliced X-box bind protein 1 (sXBP1, uXBP1). All Western blot values are normalized to the loading control tubulin and represent the mean of biological triplicates $(n=3)$. qPCR data represent the mean of 6 to 8 replicates $(n=6-8)$. Error bars indicate the standard error. * Indicates significant one-way ANOVA showing GLT and TMAO effects, where $p$-values $<0.1$ given, ${ }^{*}<0.05,{ }^{* *}<0.01,{ }^{* * *}<0.001,{ }^{* * * *}<0.0001$, or ns.

\section{Discussion}

This study is the first to demonstrate physiologically relevant TMAO effects on pancreatic $\beta$-cells under healthy and T2D-like conditions (Graphical Abstract). Our data demonstrate that TMAO recues the impaired insulin content, insulin granule levels, and ultimately the insulin secretion, in part by modulating UPR proteins to presumably enhance proper insulin protein folding. To mimic the serum TMAO levels of healthy and chronic disease patients, we cultured INS-1 $\beta$-cells and primary rat islets in the presence of 0.3 to $160 \mu \mathrm{M}$ TMAO concentrations [16,20,67-74]. Serum TMAO accumulates after a single meal rich in precursor nutrients and remains elevated for the duration of the diet $[13,16,87,90,91]$. Despite variability among diets and patients, serum TMAO levels are typically low in healthy subjects, ranging from 1 to $3 \mu \mathrm{M}$, which increases to $15 \mu \mathrm{M}$ with old age $[8,16,67,87-89]$. The onset of Western-diet-driven chronic diseases elevates TMAO to concentrations from 7 and $170 \mu \mathrm{M}$, with kidney disease patients showing the highest levels and T2D or CVD patients showing levels at or above $20 \mu \mathrm{M}[5,25,68,70,72,74,75,79-86]$. We observed significant TMAO effects within this concentration range in the SCC and GLT cultures. The most physiologically relevant treatment combinations of this study include the lower TMAO concentrations in SCC and the higher TMAO concentrations in GLT con- 
ditions. The higher TMAO levels in SCC and the lower levels in GLT conditions represent in vitro study controls. Therefore, while we found that $\beta$-cells cultured with supraphysiological concentrations of 80 and $160 \mu \mathrm{M}$ TMAO in SCC had impaired mitochondrial viability and GSIS (Figures $1 \mathrm{~A}$ and $2 \mathrm{~A}, \mathrm{E}$ ), these results are less physiologically relevant. Conversely, the beneficial TMAO phenotype we observed in GLT cultured INS- $1 \beta$-cells and primary rat islets with $40 \mu \mathrm{M}$ TMAO demonstrated normalized insulin secretion and content (Figure 2C,D,G,H), insulin granule density (Figure 3), and upregulated IRE1 $\alpha$ UPR (Figure 5) relevant to the diet-induced T2D $\beta$-cell physiology (Graphical Abstract). Future studies on primary human islets and in vivo models may further validate the clinical relevance of these results.

The GLT condition models hyperglycemia and hyperlipidemia, which drive $\beta$-cell damage indicative of diet-induced T2D [51]. Hyperglycemia, or its model glucotoxicity, is a hallmark of early- and late-stage T2D pathogenesis [51,52,119]. Hyperlipidemia accompanies obesity and T2D and is modeled by cultures high in free fatty acids, especially palmitate, as previously studied by the authors $[63-66,120]$. Because hyperglycemia precedes hyperlipidemia, the GLT condition replicates physiologically relevant synergistic effects [63]. In $\beta$-cells, ROS easily overcomes the limited endogenous antioxidant defense system and stunts functional $\beta$-cell mass (Figures 1-3) $[42-44,118,121]$. Our data support this framework because GLT decreased the GSH concentration and redox potential; however, TMAO showed no effect on this oxidative mechanism (Figure 4A,C). The beneficial TMAO phenotype we observed on $\beta$-cell function corresponds with increased IRE $1 \alpha$ and decreased P-PERK protein levels during GLT-induced ER stress. $\beta$-cell function begins with insulin production via translation and folding at the ER, followed by maturation into secretory granules [41,45,46,122-131]. Therefore, ER stress and accumulation of unfolded proteins at the ER plays a major role in T2D $\beta$-cell damage [115,132-134]. Indeed, human, animal, and in vitro T2D studies show elevated levels of ER stress and demonstrated that reducing ER stress can recover healthy $\beta$-cell function [135-137]. The various arms of the UPR can maintain or modify ER function in response to ER stress or induce apoptosis during severe conditions $[133,138-140]$. The p-PERK and IRE1 $\alpha$ arms are activated by accumulated unfolded proteins and are specifically linked with T2D $\beta$-cell dysfunction modeled by GLT $[134,138,139,141]$. The p-PERK arm limits protein translation rates to reduce the load of proteins in the ER and can trigger apoptosis via its downstream target ATF4 $[139,140]$. Our data (Figures 1D and 5A-E) support this framework. We found that $40 \mu \mathrm{M}$ TMAO reduced p-PERK but not ATF4 expression (Figure $5 \mathrm{~A}, \mathrm{~B}, \mathrm{E}, \mathrm{G}$ ) nor survival rates (Figure 2D). While our study does not identify the whole p-PERK arm as part of the beneficial TMAO mechanism, others studies show closer associations between PERK and TMAO, albeit at supraphysiological concentrations or in other cell types [6,121]. Instead, we propose that TMAO shifts the UPR toward the IRE1 $\alpha$ arm, which increases the ER protein folding capacity $[134,138,139,141]$. Low IRE1 $\alpha$ expression, as shown in the GLT condition (Figure $5 \mathrm{~F}, \mathrm{G}$ ), specifically increases $\beta$-cell susceptibility to ER stress in the context of T2D $[133,138,142]$. Indeed, IRE1 $\alpha$-deficient $\beta$-cells and mice demonstrate hyperglycemia and hypoinsulinemia and impaired insulin production, which recapitulates the GLT effect on cultured $\beta$-cells and islets, which we observed (Figure 2) [133,143-146]. Furthermore, these studies link the IRE1 $\alpha$ pathway with adaptive autophagy mechanisms that enhance islet function similar to the beneficial TMAO phenotype we observed [133,143-145]. TMAO is also defined as a direct protein folding chaperone, independent of its action on protein expression [35,147-155]. Molecular dynamics studies reveal that TMAO acts as a surfactant between the folding protein and the aqueous ER environment to selectively stabilize collapsing proteins $[29,31,156-158]$. Therefore, our results add to others that identify beneficial molecular TMAO effects on metabolic tissue function. We conclude that $40 \mu \mathrm{M}$ TMAO normalizes $\beta$-cell function by activating the IRE1 $\alpha$ UPR to maintain insulin production and granule formation despite GLT-induced ER stress.

While we demonstrate beneficial TMAO effects on $\beta$-cell function, some studies using other tissue types counter this conclusion $[6,159]$. Human and animal in vivo studies show 
improved hyperglycemia and hyperlipidemia $[11,28,160,161]$. While the glucose tolerance test (GTT) results of these studies may point toward deleterious TMAO effects on $\beta$-cells, this method did not directly quantify $\beta$-cell function through mathematical modeling [162] Instead, these studies correlated the blood glucose level changes with altered insulin responsivity in the target tissue function [163-169]. While these studies generally conclude deleterious TMAO effects in various metabolic tissues, none have investigated TMAO effects directly at the $\beta$-cell level, which is critical to T2D pathogenesis $[6,21,24-28]$.

Although some studies contradict our findings as discussed above, others corroborate that TMAO protects against T2D conditions $[30,110,170,171]$. In vitro studies of other metabolic tissues demonstrate that reduced TMAO levels exacerbate cellular damage, while elevated TMAO levels recover healthy phenotypes [171-174]. A study on TMAOtreated diabetic mice showed fewer neuropathy symptoms and identified TMAO as a protective protein folding chaperone [175]. Like $\beta$-cells, the neuronal secretory function relies on proper ER protein folding and secretion mechanisms. Together, these studies begin to highlight the beneficial roles of TMAO across various metabolic tissues.

Although this study is the first to identify the TMAO effects directly at the $\beta$-cell, another study agrees that TMAO benefits glucose tolerance in HFD-fed T2D mice [170]. This showed that the HFD-fed mice with experimentally elevated serum TMAO levels performed better on a GTT compared to control mice. A GSIS experiment on isolated islets cultured with TMAO in this study also demonstrated beneficial TMAO effects on insulin secretion [170]. Although this study did not report serum TMAO levels, this in vivo study closely approximated the beneficial effects we observed in T2D $\beta$-cells and rat islets treated with $40 \mu \mathrm{M}$ TMAO [170].

\section{Conclusions}

We conclude that acute 40. $\mu \mathrm{M}$ TMAO treatment maintains healthy $\beta$-cell function during the GLT-mediated T2D condition by normalizing insulin granule formation, increasing the IRE $1 \alpha$, and decreasing the p-PERK UPR. Further evaluation of TMAO on primary human islets or via in vivo studies will provide clearer insight into the protective effects we observed here. Since the landmark study identifying TMAO as a biomarker of CVD only 10 years ago, a general role for TMAO across chronic diseases has been debated, and some suggest that TMAO effects in the context of T2D may differ from those typically supported by CVD research $[8,9,23,25,30,176-180]$. Indeed, it is proposed that TMAO may initiate protective or compensatory cellular responses to diet-mediated metabolic diseases $[23,181,182]$. Our data demonstrate crucial findings to support such a context-dependent role for TMAO and suggest that TMAO acts as a signal from the diet-microbiome interaction to metabolic tissues to trigger adaptive cellular responses to the overnutrition-driven cellular stress. We propose that at the $\beta$-cell, acute TMAO initiates protective effects that may mitigate diet-mediated T2D pathogenesis.

Supplementary Materials: The following are available online at https:/ / www.mdpi.com/article/ 10.3390/biom11121892/s1, Figure S1. Glucolipotoxicity (GLT) component effects on INS-1 $\beta$-cell glucose stimulated insulin secretion (GSIS) and prolifer-ation. Figure S2. Flow cytometry gating criteria for INS-1 $\beta$-cell survival analysis.

Author Contributions: Conceptualization, data curation, project administration, E.S.K. and J.S.T.; methodology, E.S.K., J.L.B., K.B.R., W.S.E., J.R.D., J.M.H. (Jackson M. Hansen), A.P.N., J.M.H. (Jason M. Hansen) and J.S.T.; formal analysis, investigation, E.S.K., J.L.B., K.B.R., W.S.E., J.R.D., J.M.H. (Jackson M. Hansen), J.M.H. (Jason M. Hansen) and J.S.T.; resources, J.M.H. (Jason M. Hansen) and J.S.T.; writing—original draft preparation, E.S.K.; writing—review and editing, E.S.K., J.L.B., K.B.R., W.S.E., J.R.D., J.M.H. (Jackson M. Hansen), A.P.N., J.M.H. (Jason M. Hansen) and J.S.T.; supervision, J.M.H. (Jason M. Hansen) and J.S.T.; funding acquisition, J.S.T. All authors have read and agreed to the published version of the manuscript.

Funding: This research was funded by the United States Department of Agriculture, grant number USDA-AFRI 2020-67017-30846. 
Institutional Review Board Statement: The study was conducted according to the guidelines of the Declaration of Helsinki and approved by the BYU Institutional Review Board (protocol code 19-1002, $11 / 10 / 2019)$.

Acknowledgments: We thank Michael Standing at the BYU Electron Microscopy Facility for assistance in the sample preparation and STEM imaging. We thank Jason Kenealey, Chad Hancock, and the Tessem lab members for critical discussions and evaluation of the data and manuscript.

Conflicts of Interest: The authors declare no conflict of interest. The funders had no role in the design of the study; in the collection, analyses, or interpretation of data; in the writing of the manuscript, or in the decision to publish the results.

\section{References}

1. Kones, R.; Rumana, U. Cardiometabolic diseases of civilization: History and maturation of an evolving global threat. An update and call to action. Ann. Med. 2017, 49, 260-274. [CrossRef]

2. Stanhope, K.L.; Goran, M.I.; Bosy-Westphal, A.; King, J.C.; Schmidt, L.A.; Schwarz, J.M.; Stice, E.; Sylvetsky, A.C.; Turnbaugh, P.J.; Bray, G.A.; et al. Pathways and mechanisms linking dietary components to cardiometabolic disease: Thinking beyond calories. Obes. Rev. 2018, 19, 1205-1235. [CrossRef]

3. Kopp, W. How Western Diet and Lifestyle Drive the Pandemic of Obesity And Civilization Diseases. Diabetes Metab. Syndr. Obes. Targets Ther. 2019, 12, 2221-2236. [CrossRef] [PubMed]

4. Shan, Z.; Sun, T.; Huang, H.; Chen, S.; Chen, L.; Luo, C.; Yang, W.; Yang, X.; Yao, P.; Cheng, J.; et al. Association between microbiota-dependent metabolite trimethylamine-N-oxide and type 2 diabetes. Am. J. Clin. Nutr. 2017, 106, 888-894. [CrossRef] [PubMed]

5. $\quad$ Svingen, G.F.; Schartum-Hansen, H.; Pedersen, E.R.; Ueland, P.M.; Tell, G.S.; Mellgren, G.; Njolstad, P.R.; Seifert, R.; Strand, E.; Karlsson, T.; et al. Prospective Associations of Systemic and Urinary Choline Metabolites with Incident Type 2 Diabetes. Clin. Chem. 2016, 62, 755-765. [CrossRef]

6. Chen, S.; Henderson, A.; Petriello, M.C.; Romano, K.A.; Gearing, M.; Miao, J.; Schell, M.; Sandoval-Espinola, W.J.; Tao, J.; Sha, B.; et al. Trimethylamine N-Oxide Binds and Activates PERK to Promote Metabolic Dysfunction. Cell Metab. 2019, 30, 1141-1151.e5. [CrossRef] [PubMed]

7. Obeid, R.; Awwad, H.M.; Rabagny, Y.; Graeber, S.; Herrmann, W.; Geisel, J. Plasma trimethylamine N-oxide concentration is associated with choline, phospholipids, and methyl metabolism. Am. J. Clin. Nutr. 2016, 103, 703-711. [CrossRef]

8. Wang, Z.; Klipfell, E.; Bennett, B.J.; Koeth, R.; Levison, B.S.; Dugar, B.; Feldstein, A.E.; Britt, E.B.; Fu, X.; Chung, Y.M.; et al. Gut flora metabolism of phosphatidylcholine promotes cardiovascular disease. Nature 2011, 472, 57-63. [CrossRef]

9. Velasquez, M.T.; Ramezani, A.; Manal, A.; Raj, D.S. Trimethylamine N-Oxide: The Good, the Bad and the Unknown. Toxins 2016, 8, 326. [CrossRef]

10. Yang, J.J.; Lipworth, L.P.; Shu, X.O.; Blot, W.J.; Xiang, Y.B.; Steinwandel, M.D.; Li, H.; Gao, Y.T.; Zheng, W.; Yu, D. Associations of choline-related nutrients with cardiometabolic and all-cause mortality: Results from 3 prospective cohort studies of blacks, whites, and Chinese. Am. J. Clin. Nutr. 2020, 111, 644-656. [CrossRef] [PubMed]

11. Argyridou, S.; Davies, M.J.; Biddle, G.J.H.; Bernieh, D.; Suzuki, T.; Dawkins, N.P.; Rowlands, A.V.; Khunti, K.; Smith, A.C.; Yates, T. Evaluation of an 8-Week Vegan Diet on Plasma Trimethylamine-N-Oxide and Postchallenge Glucose in Adults with Dysglycemia or Obesity. J. Nutr. 2021, 151, 1844-1853. [CrossRef] [PubMed]

12. Zeisel, S.H.; Wishnok, J.S.; Blusztajn, J.K. Formation of methylamines from ingested choline and lecithin. J. Pharmacol. Exp. Ther. 1983, 225, 320-324.

13. Rebouche, C.J.; Chenard, C.A. Metabolic fate of dietary carnitine in human adults: Identification and quantification of urinary and fecal metabolites. J. Nutr. 1991, 121, 539-546. [CrossRef]

14. Al-Waiz, M.; Mitchell, S.C.; Idle, J.R.; Smith, R.L. The metabolism of 14C-labelled trimethylamine and its N-oxide in man. Xenobiotica 1987, 17, 551-558. [CrossRef]

15. Ufnal, M.; Zadlo, A.; Ostaszewski, R. TMAO: A small molecule of great expectations. Nutrition 2015, 31, 1317-1323. [CrossRef]

16. Mitchell, S.M.; Milan, A.M.; Mitchell, C.J.; Gillies, N.A.; D'Souza, R.F.; Zeng, N.; Ramzan, F.; Sharma, P.; Knowles, S.O.; Roy, N.C.; et al. Protein Intake at Twice the RDA in Older Men Increases Circulatory Concentrations of the Microbiome Metabolite Trimethylamine- $\mathrm{N}$-Oxide (TMAO). Nutrients 2019, 11, 2207. [CrossRef]

17. Martinez-del Campo, A.; Bodea, S.; Hamer, H.A.; Marks, J.A.; Haiser, H.J.; Turnbaugh, P.J.; Balskus, E.P. Characterization and detection of a widely distributed gene cluster that predicts anaerobic choline utilization by human gut bacteria. $m B i o$ 2015, 6 , e00042-15. [CrossRef]

18. Krueger, S.K.; Williams, D.E. Mammalian flavin-containing monooxygenases: Structure/function, genetic polymorphisms and role in drug metabolism. Pharmacol. Ther. 2005, 106, 357-387. [CrossRef] [PubMed]

19. Canyelles, M.; Tondo, M.; Cedo, L.; Farras, M.; Escola-Gil, J.C.; Blanco-Vaca, F. Trimethylamine N-Oxide: A Link among Diet, Gut Microbiota, Gene Regulation of Liver and Intestine Cholesterol Homeostasis and HDL Function. Int. J. Mol. Sci. 2018, 19, 3228. [CrossRef] [PubMed] 
20. Koeth, R.A.; Wang, Z.; Levison, B.S.; Buffa, J.A.; Org, E.; Sheehy, B.T.; Britt, E.B.; Fu, X.; Wu, Y.; Li, L.; et al. Intestinal microbiota metabolism of L-carnitine, a nutrient in red meat, promotes atherosclerosis. Nat. Med. 2013, 19, 576-585. [CrossRef] [PubMed]

21. Claesson, M.J.; Jeffery, I.B.; Conde, S.; Power, S.E.; O’Connor, E.M.; Cusack, S.; Harris, H.M.; Coakley, M.; Lakshminarayanan, B.; O'Sullivan, O.; et al. Gut microbiota composition correlates with diet and health in the elderly. Nature 2012, 488, 178-184. [CrossRef] [PubMed]

22. Brunt, V.E.; Gioscia-Ryan, R.A.; Richey, J.J.; Zigler, M.C.; Cuevas, L.M.; Gonzalez, A.; Vazquez-Baeza, Y.; Battson, M.L.; Smithson, A.T.; Gilley, A.D.; et al. Suppression of the gut microbiome ameliorates age-related arterial dysfunction and oxidative stress in mice. J. Physiol. 2019, 597, 2361-2378. [CrossRef]

23. Krueger, E.S.; Lloyd, T.S.; Tessem, J.S. The Accumulation and Molecular Effects of Trimethylamine N-Oxide on Metabolic Tissues: It's Not All Bad. Nutrients 2021, 13, 2873. [CrossRef] [PubMed]

24. Chen, M.L.; Zhu, X.H.; Ran, L.; Lang, H.D.; Yi, L.; Mi, M.T. Trimethylamine-N-Oxide Induces Vascular Inflammation by Activating the NLRP3 Inflammasome through the SIRT3-SOD2-mtROS Signaling Pathway. J. Am. Heart. Assoc. 2017, 6, e006347. [CrossRef]

25. Lever, M.; George, P.M.; Slow, S.; Bellamy, D.; Young, J.M.; Ho, M.; McEntyre, C.J.; Elmslie, J.L.; Atkinson, W.; Molyneux, S.L.; et al. Betaine and Trimethylamine- $\mathrm{N}$-Oxide as Predictors of Cardiovascular Outcomes Show Different Patterns in Diabetes Mellitus: An Observational Study. PLoS ONE 2014, 9, e114969. [CrossRef]

26. Mueller, D.M.; Allenspach, M.; Othman, A.; Saely, C.H.; Muendlein, A.; Vonbank, A.; Drexel, H.; von Eckardstein, A. Plasma levels of trimethylamine- $\mathrm{N}$-oxide are confounded by impaired kidney function and poor metabolic control. Atherosclerosis 2015, 243, 638-644. [CrossRef] [PubMed]

27. Dambrova, M.; Latkovskis, G.; Kuka, J.; Strele, I.; Konrade, I.; Grinberga, S.; Hartmane, D.; Pugovics, O.; Erglis, A.; Liepinsh, E. Diabetes is Associated with Higher Trimethylamine N-oxide Plasma Levels. Exp. Clin. Endocrinol. Diabetes 2016, 124, 251-256. [CrossRef]

28. Miao, J.; Ling, A.V.; Manthena, P.V.; Gearing, M.E.; Graham, M.J.; Crooke, R.M.; Croce, K.J.; Esquejo, R.M.; Clish, C.B.; Vicent, D.; et al. Flavin-containing monooxygenase 3 as a potential player in diabetes-associated atherosclerosis. Nat. Commun. 2015, 6, 6498. [CrossRef] [PubMed]

29. Liao, Y.T.; Manson, A.C.; DeLyser, M.R.; Noid, W.G.; Cremer, P.S. Trimethylamine N-oxide stabilizes proteins via a distinct mechanism compared with betaine and glycine. Proc. Natl. Acad. Sci. USA 2017, 114, 2479-2484. [CrossRef]

30. Zhao, Z.H.; Xin, F.Z.; Zhou, D.; Xue, Y.Q.; Liu, X.L.; Yang, R.X.; Pan, Q.; Fan, J.G. Trimethylamine N-oxide attenuates high-fat high-cholesterol diet-induced steatohepatitis by reducing hepatic cholesterol overload in rats. World J. Gastroenterol. 2019, 25, 2450-2462. [CrossRef]

31. Mondal, J.; Stirnemann, G.; Berne, B.J. When does trimethylamine N-oxide fold a polymer chain and urea unfold it? J. Phys. Chem. B 2013, 117, 8723-8732. [CrossRef] [PubMed]

32. Song, J.L.; Chuang, D.T. Natural osmolyte trimethylamine $N$-oxide corrects assembly defects of mutant branched-chain $\alpha$-ketoacid decarboxylase in maple syrup urine disease. J. Biol. Chem. 2001, 276, 40241-40246. [CrossRef]

33. Sackett, D.L. Natural osmolyte trimethylamine $N$-oxide stimulates tubulin polymerization and reverses urea inhibition. Am. J. Physiol. 1997, 273, R669-R676. [CrossRef]

34. Villalobos, A.R.; Renfro, J.L. Trimethylamine oxide suppresses stress-induced alteration of organic anion transport in choroid plexus. J. Exp. Biol. 2007, 210, 541-552. [CrossRef]

35. Wang, A.; Bolen, D.W. A naturally occurring protective system in urea-rich cells: Mechanism of osmolyte protection of proteins against urea denaturation. Biochemistry 1997, 36, 9101-9108. [CrossRef]

36. Steiner, D.J.; Kim, A.; Miller, K.; Hara, M. Pancreatic islet plasticity: Interspecies comparison of islet architecture and composition. Islets 2010, 2, 135-145. [CrossRef] [PubMed]

37. Ionescu-Tirgoviste, C.; Gagniuc, P.A.; Gubceac, E.; Mardare, L.; Popescu, I.; Dima, S.; Militaru, M. A 3D map of the islet routes throughout the healthy human pancreas. Sci. Rep. 2015, 5, 14634. [CrossRef] [PubMed]

38. Wang, X.; Misawa, R.; Zielinski, M.C.; Cowen, P.; Jo, J.; Periwal, V.; Ricordi, C.; Khan, A.; Szust, J.; Shen, J.; et al. Regional differences in islet distribution in the human pancreas-Preferential beta-cell loss in the head region in patients with type 2 diabetes. PLoS ONE 2013, 8, e67454. [CrossRef]

39. Tiedge, M.; Lenzen, S. Regulation of glucokinase and GLUT-2 glucose-transporter gene expression in pancreatic B-cells. Biochem. J. 1991, 279 Pt 3, 899-901. [CrossRef]

40. Schuit, F.C.; De Vos, A.; Moens, K.; Quartier, E.; Heimberg, H. Glucose-induced B-cell recruitment and the expression of hexokinase isoenzymes. Adv. Exp. Med. Biol. 1997, 426, 259-266. [CrossRef]

41. Boland, B.B.; Rhodes, C.J.; Grimsby, J.S. The dynamic plasticity of insulin production in $\beta$-cells. Mol. Metab. 2017, 6, 958-973. [CrossRef] [PubMed]

42. Ghemrawi, R.; Battaglia-Hsu, S.F.; Arnold, C. Endoplasmic Reticulum Stress in Metabolic Disorders. Cells 2018, 7, 63. [CrossRef]

43. Tiedge, M.; Lortz, S.; Drinkgern, J.; Lenzen, S. Relation between antioxidant enzyme gene expression and antioxidative defense status of insulin-producing cells. Diabetes 1997, 46, 1733-1742. [CrossRef] [PubMed]

44. Welsh, N.; Margulis, B.; Borg, L.A.; Wiklund, H.J.; Saldeen, J.; Flodstrom, M.; Mello, M.A.; Andersson, A.; Pipeleers, D.G.; Hellerstrom, C.; et al. Differences in the expression of heat-shock proteins and antioxidant enzymes between human and rodent pancreatic islets: Implications for the pathogenesis of insulin-dependent diabetes mellitus. Mol. Med. 1995, 1, 806-820. [CrossRef] [PubMed] 
45. Steiner, D.F.; Cunningham, D.; Spigelman, L.; Aten, B. Insulin biosynthesis: Evidence for a precursor. Science 1967, 157, 697-700. [CrossRef] [PubMed]

46. Steiner, D.F.; Terris, S.; Chan, S.J.; Rubenstein, A.H. Chemical and biological aspects of insulin and proinsulin. Acta Med. Scand. Suppl. 1976, 601, 55-107. [PubMed]

47. Kanda, Y.; Hashiramoto, M.; Shimoda, M.; Hamamoto, S.; Tawaramoto, K.; Kimura, T.; Hirukawa, H.; Nakashima, K.; Kaku, K. Dietary restriction preserves the mass and function of pancreatic $\beta$ cells via cell kinetic regulation and suppression of oxidative/ER stress in diabetic mice. J. Nutr. Biochem. 2015, 26, 219-226. [CrossRef]

48. Weir, G.C.; Gaglia, J.; Bonner-Weir, S. Inadequate $\beta$-cell mass is essential for the pathogenesis of type 2 diabetes. Lancet Diabetes Endocrinol. 2020, 8, 249-256. [CrossRef]

49. Chen, C.; Cohrs, C.M.; Stertmann, J.; Bozsak, R.; Speier, S. Human beta cell mass and function in diabetes: Recent advances in knowledge and technologies to understand disease pathogenesis. Mol. Metab. 2017, 6, 943-957. [CrossRef]

50. Jensen, D.M.; Hendricks, K.V.; Mason, A.T.; Tessem, J.S. Good Cop, Bad Cop: The Opposing Effects of Macrophage Activation State on Maintaining or Damaging Functional $\beta$-Cell Mass. Metabolites 2020, 10, 485. [CrossRef]

51. Poitout, V.; Robertson, R.P. Glucolipotoxicity: Fuel excess and $\beta$-cell dysfunction. Endocr. Rev. 2008, 29, 351-366. [CrossRef] [PubMed]

52. Alejandro, E.U.; Gregg, B.; Blandino-Rosano, M.; Cras-Meneur, C.; Bernal-Mizrachi, E. Natural history of $\beta$-cell adaptation and failure in type 2 diabetes. Mol. Asp. Med. 2015, 42, 19-41. [CrossRef] [PubMed]

53. Hudish, L.I.; Reusch, J.E.; Sussel, L. $\beta$ Cell dysfunction during progression of metabolic syndrome to type 2 diabetes. J. Clin. Investig. 2019, 129, 4001-4008. [CrossRef]

54. Jesinkey, S.R.; Madiraju, A.K.; Alves, T.C.; Yarborough, O.H.; Cardone, R.L.; Zhao, X.; Parsaei, Y.; Nasiri, A.R.; Butrico, G.; Liu, X.; et al. Mitochondrial GTP Links Nutrient Sensing to $\beta$ Cell Health, Mitochondrial Morphology, and Insulin Secretion Independent of OxPhos. Cell Rep. 2019, 28, 759-772.e10. [CrossRef]

55. Bitner, B.F.; Ray, J.D.; Kener, K.B.; Herring, J.A.; Tueller, J.A.; Johnson, D.K.; Tellez Freitas, C.M.; Fausnacht, D.W.; Allen, M.E.; Thomson, A.H.; et al. Common gut microbial metabolites of dietary flavonoids exert potent protective activities in $\beta$-cells and skeletal muscle cells. J. Nutr. Biochem. 2018, 62, 95-107. [CrossRef] [PubMed]

56. Hohmeier, H.E.; Mulder, H.; Chen, G.; Henkel-Rieger, R.; Prentki, M.; Newgard, C.B. Isolation of INS-1-derived cell lines with robust ATP-sensitive K+ channel-dependent and -independent glucose-stimulated insulin secretion. Diabetes 2000, 49, 424-430. [CrossRef] [PubMed]

57. Tessem, J.S.; Moss, L.G.; Chao, L.C.; Arlotto, M.; Lu, D.; Jensen, M.V.; Stephens, S.B.; Tontonoz, P.; Hohmeier, H.E.; Newgard, C.B. Nkx6.1 regulates islet $\beta$-cell proliferation via Nr4a1 and Nr4a3 nuclear receptors. Proc. Natl. Acad. Sci. USA 2014, 111, 5242-5247. [CrossRef]

58. Schisler, J.C.; Fueger, P.T.; Babu, D.A.; Hohmeier, H.E.; Tessem, J.S.; Lu, D.; Becker, T.C.; Naziruddin, B.; Levy, M.; Mirmira, R.G.; et al. Stimulation of human and rat islet $\beta$-cell proliferation with retention of function by the homeodomain transcription factor Nkx6.1. Mol. Cell. Biol. 2008, 28, 3465-3476. [CrossRef]

59. Johnson, J.H.; Crider, B.P.; Mccorkle, K.; Alford, M.; Unger, R.H. Inhibition of Glucose-Transport into Rat Islet Cells by Immunoglobulins from Patients with New-Onset Insulin-Dependent Diabetes-Mellitus. N. Engl. J. Med. 1990, 322, 653-659. [CrossRef]

60. Veluthakal, R.; Arora, D.K.; Goalstone, M.L.; Kowluru, R.A.; Kowluru, A. Metabolic Stress Induces Caspase-3 Mediated Degradation and Inactivation of Farnesyl and Geranylgeranyl Transferase Activities in Pancreatic $\beta$-Cells. Cell. Physiol. Biochem. 2016, 39, 2110-2120. [CrossRef] [PubMed]

61. Veluthakal, R.; Suresh, M.V.; Kowluru, A. Down-regulation of expression and function of nucleoside diphosphate kinase in insulin-secreting $\beta$-cells under in vitro conditions of glucolipotoxicity. Mol. Cell. Biochem. 2009, 329, 121-129. [CrossRef]

62. Kornelius, E.; Li, H.H.; Peng, C.H.; Yang, Y.S.; Chen, W.J.; Chang, Y.Z.; Bai, Y.C.; Liu, S.; Huang, C.N.; Lin, C.L. Liraglutide protects against glucolipotoxicity-induced RIN-m5F $\beta$-cell apoptosis through restoration of PDX1 expression. J. Cell. Mol. Med. 2019, 23, 619-629. [CrossRef] [PubMed]

63. Prentki, M.; Joly, E.; El-Assaad, W.; Roduit, R. Malonyl-CoA signaling, lipid partitioning, and glucolipotoxicity: Role in $\beta$-cell adaptation and failure in the etiology of diabetes. Diabetes 2002, 51 (Suppl. 3), S405-S413. [CrossRef] [PubMed]

64. Alsabeeh, N.; Chausse, B.; Kakimoto, P.A.; Kowaltowski, A.J.; Shirihai, O. Cell culture models of fatty acid overload: Problems and solutions. Biochim. Biophys. Acta Mol. Cell Biol. Lipids 2018, 1863, 143-151. [CrossRef]

65. Oliveira, A.F.; Cunha, D.A.; Ladriere, L.; Igoillo-Esteve, M.; Bugliani, M.; Marchetti, P.; Cnop, M. In vitro use of free fatty acids bound to albumin: A comparison of protocols. Biotechniques 2015, 58, 228-233. [CrossRef]

66. Paolisso, G.; Tataranni, P.A.; Foley, J.E.; Bogardus, C.; Howard, B.V.; Ravussin, E. A high concentration of fasting plasma non-esterified fatty acids is a risk factor for the development of NIDDM. Diabetologia 1995, 38, 1213-1217. [CrossRef]

67. Garcia, E.; Wolak-Dinsmore, J.; Wang, Z.; Li, X.S.; Bennett, D.W.; Connelly, M.A.; Otvos, J.D.; Hazen, S.L.; Jeyarajah, E.J. NMR quantification of trimethylamine-N-oxide in human serum and plasma in the clinical laboratory setting. Clin. Biochem. 2017, 50, 947-955. [CrossRef] [PubMed]

68. Prokopienko, A.J.; West, R.E., 3rd; Schrum, D.P.; Stubbs, J.R.; Leblond, F.A.; Pichette, V.; Nolin, T.D. Metabolic Activation of Flavin Monooxygenase-mediated Trimethylamine-N-Oxide Formation in Experimental Kidney Disease. Sci. Rep. 2019, 9, 15901. [CrossRef] 
69. Johnson, C.; Prokopienko, A.J.; West, R.E., 3rd; Nolin, T.D.; Stubbs, J.R. Decreased Kidney Function Is Associated with Enhanced Hepatic Flavin Monooxygenase Activity and Increased Circulating Trimethylamine N-Oxide Concentrations in Mice. Drug Metab. Dispos. 2018, 46, 1304-1309. [CrossRef]

70. Stubbs, J.R.; House, J.A.; Ocque, A.J.; Zhang, S.; Johnson, C.; Kimber, C.; Schmidt, K.; Gupta, A.; Wetmore, J.B.; Nolin, T.D.; et al. Serum Trimethylamine-N-Oxide is Elevated in CKD and Correlates with Coronary Atherosclerosis Burden. J. Am. Soc. Nephrol. 2016, 27, 305-313. [CrossRef]

71. Gupta, N.; Buffa, J.A.; Roberts, A.B.; Sangwan, N.; Skye, S.M.; Li, L.; Ho, K.J.; Varga, J.; DiDonato, J.A.; Tang, W.H.W.; et al. Targeted Inhibition of Gut Microbial Trimethylamine N-Oxide Production Reduces Renal Tubulointerstitial Fibrosis and Functional Impairment in a Murine Model of Chronic Kidney Disease. Arterioscler. Thromb. Vasc. Biol. 2020, 40, 1239-1255. [CrossRef]

72. Al-Obaide, M.A.I.; Singh, R.; Datta, P.; Rewers-Felkins, K.A.; Salguero, M.V.; Al-Obaidi, I.; Kottapalli, K.R.; Vasylyeva, T.L. Gut Microbiota-Dependent Trimethylamine- $N$-oxide and Serum Biomarkers in Patients with T2DM and Advanced CKD. J. Clin. Med. 2017, 6, 86. [CrossRef] [PubMed]

73. Xu, K.Y.; Xia, G.H.; Lu, J.Q.; Chen, M.X.; Zhen, X.; Wang, S.; You, C.; Nie, J.; Zhou, H.W.; Yin, J. Impaired renal function and dysbiosis of gut microbiota contribute to increased trimethylamine- $N$-oxide in chronic kidney disease patients. Sci. Rep. 2017, 7, 1445. [CrossRef]

74. Tang, W.H.; Wang, Z.; Kennedy, D.J.; Wu, Y.; Buffa, J.A.; Agatisa-Boyle, B.; Li, X.S.; Levison, B.S.; Hazen, S.L. Gut microbiotadependent trimethylamine $\mathrm{N}$-oxide (TMAO) pathway contributes to both development of renal insufficiency and mortality risk in chronic kidney disease. Circ. Res. 2015, 116, 448-455. [CrossRef]

75. Barrea, L.; Annunziata, G.; Muscogiuri, G.; Di Somma, C.; Laudisio, D.; Maisto, M.; de Alteriis, G.; Tenore, G.C.; Colao, A.; Savastano, S. Trimethylamine- $N$-oxide (TMAO) as Novel Potential Biomarker of Early Predictors of Metabolic Syndrome. Nutrients 2018, 10, 1971. [CrossRef] [PubMed]

76. Tang, W.H.; Wang, Z.; Fan, Y.; Levison, B.; Hazen, J.E.; Donahue, L.M.; Wu, Y.; Hazen, S.L. Prognostic value of elevated levels of intestinal microbe-generated metabolite trimethylamine- $N$-oxide in patients with heart failure: Refining the gut hypothesis. J. Am. Coll. Cardiol. 2014, 64, 1908-1914. [CrossRef]

77. Tang, W.H.; Wang, Z.; Shrestha, K.; Borowski, A.G.; Wu, Y.; Troughton, R.W.; Klein, A.L.; Hazen, S.L. Intestinal microbiotadependent phosphatidylcholine metabolites, diastolic dysfunction, and adverse clinical outcomes in chronic systolic heart failure. J. Card. Fail. 2015, 21, 91-96. [CrossRef]

78. Troseid, M.; Ueland, T.; Hov, J.R.; Svardal, A.; Gregersen, I.; Dahl, C.P.; Aakhus, S.; Gude, E.; Bjorndal, B.; Halvorsen, B.; et al. Microbiota-dependent metabolite trimethylamine- $N$-oxide is associated with disease severity and survival of patients with chronic heart failure. J. Intern. Med. 2015, 277, 717-726. [CrossRef] [PubMed]

79. Schugar, R.C.; Shih, D.M.; Warrier, M.; Helsley, R.N.; Burrows, A.; Ferguson, D.; Brown, A.L.; Gromovsky, A.D.; Heine, M.; Chatterjee, A.; et al. The TMAO-Producing Enzyme Flavin-Containing Monooxygenase 3 Regulates Obesity and the Beiging of White Adipose Tissue. Cell Rep. 2017, 19, 2451-2461. [CrossRef]

80. McEntyre, C.J.; Lever, M.; Chambers, S.T.; George, P.M.; Slow, S.; Elmslie, J.L.; Florkowski, C.M.; Lunt, H.; Krebs, J.D. Variation of betaine, $N, N$-dimethylglycine, choline, glycerophosphorylcholine, taurine and trimethylamine- $N$-oxide in the plasma and urine of overweight people with type 2 diabetes over a two-year period. Ann. Clin. Biochem. 2015, 52, 352-360. [CrossRef]

81. Griffin, L.E.; Djuric, Z.; Angiletta, C.J.; Mitchell, C.M.; Baugh, M.E.; Davy, K.P.; Neilson, A.P. A Mediterranean diet does not alter plasma trimethylamine $N$-oxide concentrations in healthy adults at risk for colon cancer. Food Funct. 2019, 10, $2138-2147$. [CrossRef] [PubMed]

82. Brunt, V.E.; Gioscia-Ryan, R.A.; Casso, A.G.; VanDongen, N.S.; Ziemba, B.P.; Sapinsley, Z.J.; Richey, J.J.; Zigler, M.C.; Neilson, A.P.; Davy, K.P.; et al. Trimethylamine-N-Oxide Promotes Age-Related Vascular Oxidative Stress and Endothelial Dysfunction in Mice and Healthy Humans. Hypertension 2020, 76, 101-112. [CrossRef] [PubMed]

83. Tang, W.H.; Wang, Z.; Li, X.S.; Fan, Y.; Li, D.S.; Wu, Y.; Hazen, S.L. Increased Trimethylamine N-Oxide Portends High Mortality Risk Independent of Glycemic Control in Patients with Type 2 Diabetes Mellitus. Clin. Chem. 2017, 63, 297-306. [CrossRef] [PubMed]

84. Mafune, A.; Iwamoto, T.; Tsutsumi, Y.; Nakashima, A.; Yamamoto, I.; Yokoyama, K.; Yokoo, T.; Urashima, M. Associations among serum trimethylamine- $N$-oxide (TMAO) levels, kidney function and infarcted coronary artery number in patients undergoing cardiovascular surgery: A cross-sectional study. Clin. Exp. Nephrol. 2016, 20, 731-739. [CrossRef]

85. Missailidis, C.; Hallqvist, J.; Qureshi, A.R.; Barany, P.; Heimburger, O.; Lindholm, B.; Stenvinkel, P.; Bergman, P. Serum Trimethylamine-N-Oxide Is Strongly Related to Renal Function and Predicts Outcome in Chronic Kidney Disease. PLoS ONE 2016, 11, e0141738. [CrossRef]

86. Kaysen, G.A.; Johansen, K.L.; Chertow, G.M.; Dalrymple, L.S.; Kornak, J.; Grimes, B.; Dwyer, T.; Chassy, A.W.; Fiehn, O. Associations of Trimethylamine N-Oxide with Nutritional and Inflammatory Biomarkers and Cardiovascular Outcomes in Patients New to Dialysis. J. Ren. Nutr. 2015, 25, 351-356. [CrossRef] [PubMed]

87. Boutagy, N.E.; Neilson, A.P.; Osterberg, K.L.; Smithson, A.T.; Englund, T.R.; Davy, B.M.; Hulver, M.W.; Davy, K.P. Short-term high-fat diet increases postprandial trimethylamine-N-oxide in humans. Nutr. Res. 2015, 35, 858-864. [CrossRef]

88. Wang, Z.; Levison, B.S.; Hazen, J.E.; Donahue, L.; Li, X.M.; Hazen, S.L. Measurement of trimethylamine- $N$-oxide by stable isotope dilution liquid chromatography tandem mass spectrometry. Anal. Biochem. 2014, 455, 35-40. [CrossRef] 
89. Ilozumba, M.N.; Cheng, T.D.; Neuhouser, M.L.; Miller, J.W.; Beresford, S.A.A.; Duggan, D.J.; Toriola, A.T.; Song, X.; Zheng, Y.; Bailey, L.B.; et al. Associations between Plasma Choline Metabolites and Genetic Polymorphisms in One-Carbon Metabolism in Postmenopausal Women: The Women's Health Initiative Observational Study. J. Nutr. 2020, 150, 2874-2881. [CrossRef]

90. Cho, C.E.; Taesuwan, S.; Malysheva, O.V.; Bender, E.; Tulchinsky, N.F.; Yan, J.; Sutter, J.L.; Caudill, M.A. Trimethylamine-N-oxide (TMAO) response to animal source foods varies among healthy young men and is influenced by their gut microbiota composition: A randomized controlled trial. Mol. Nutr. Food Res. 2017, 61, 1600324. [CrossRef]

91. Wang, Z.; Bergeron, N.; Levison, B.S.; Li, X.S.; Chiu, S.; Jia, X.; Koeth, R.A.; Li, L.; Wu, Y.; Tang, W.H.W.; et al. Impact of chronic dietary red meat, white meat, or non-meat protein on trimethylamine $N$-oxide metabolism and renal excretion in healthy men and women. Eur. Heart J. 2019, 40, 583-594. [CrossRef]

92. Mosmann, T. Rapid colorimetric assay for cellular growth and survival: Application to proliferation and cytotoxicity assays. J. Immunol. Methods 1983, 65, 55-63. [CrossRef]

93. Xu, M.; McCanna, D.J.; Sivak, J.G. Use of the viability reagent PrestoBlue in comparison with alamarBlue and MTT to assess the viability of human corneal epithelial cells. J. Pharmacol. Toxicol. Methods 2015, 71, 1-7. [CrossRef]

94. Berridge, M.V.; Herst, P.M.; Tan, A.S. Tetrazolium dyes as tools in cell biology: New insights into their cellular reduction. Biotechnol. Annu. Rev. 2005, 11, 127-152. [CrossRef] [PubMed]

95. Draney, C.; Hobson, A.E.; Grover, S.G.; Jack, B.O.; Tessem, J.S. Cdk5r1 Overexpression Induces Primary $\beta$-Cell Proliferation. J. Diabetes Res. 2016, 2016, 6375804. [CrossRef] [PubMed]

96. Bauchle, C.J.; Rohli, K.E.; Boyer, C.K.; Pal, V.; Rocheleau, J.V.; Liu, S.; Imai, Y.; Taylor, E.B.; Stephens, S.B. Mitochondrial Efflux of Citrate and Isocitrate Is Fully Dispensable for Glucose-Stimulated Insulin Secretion and Pancreatic Islet $\beta$-Cell Function. Diabetes 2021, 70, 1717-1728. [CrossRef]

97. Truchan, N.A.; Brar, H.K.; Gallagher, S.J.; Neuman, J.C.; Kimple, M.E. A single-islet microplate assay to measure mouse and human islet insulin secretion. Islets 2015, 7, e1076607. [CrossRef]

98. Zhao, A.; Ohara-Imaizumi, M.; Brissova, M.; Benninger, R.K.; Xu, Y.; Hao, Y.; Abramowitz, J.; Boulay, G.; Powers, A.C.; Piston, D.; et al. G $\alpha$ o represses insulin secretion by reducing vesicular docking in pancreatic $\beta$-cells. Diabetes 2010, 59, $2522-2529$. [CrossRef]

99. Wang, L.; Gong, Y.; Li, C.; Zu, Y.; Cui, S.; Wan, L.; Chen, X. Pericentrin expression in pancreatic $\beta$ cells is associated impaired glucose tolerance. Am. J. Transl. Res. 2019, 11, 2257-2268. [PubMed]

100. Jones, D.P. Redox potential of GSH/GSSG couple: Assay and biological significance. Methods Enzymol. 2002, 348, 93-112. [CrossRef]

101. Rowley, T.J., IV; Bitner, B.F.; Ray, J.D.; Lathen, D.R.; Smithson, A.T.; Dallon, B.W.; Plowman, C.J.; Bikman, B.T.; Hansen, J.M.; Dorenkott, M.R.; et al. Monomeric cocoa catechins enhance $\beta$-cell function by increasing mitochondrial respiration. J. Nutr. Biochem. 2017, 49, 30-41. [CrossRef]

102. Kirlin, W.G.; Cai, J.; Thompson, S.A.; Diaz, D.; Kavanagh, T.J.; Jones, D.P. Glutathione redox potential in response to differentiation and enzyme inducers. Free Radic. Biol. Med. 1999, 27, 1208-1218. [CrossRef]

103. Harris, C.; Hansen, J.M. Oxidative stress, thiols, and redox profiles. Methods Mol. Biol. 2012, 889, 325-346. [CrossRef] [PubMed]

104. Jones, D.P.; Carlson, J.L.; Mody, V.C.; Cai, J.; Lynn, M.J.; Sternberg, P. Redox state of glutathione in human plasma. Free Radic. Biol. Med. 2000, 28, 625-635. [CrossRef]

105. Draney, C.; Austin, M.C.; Leifer, A.H.; Smith, C.J.; Kener, K.B.; Aitken, T.J.; Hess, K.H.; Haines, A.C.; Lett, L.A.; Hernandez-Carretero, A.; et al. HDAC1 overexpression enhances $\beta$-cell proliferation by down-regulating Cdkn1b/p27. Biochem. J. 2018, 475, 3997-4010. [CrossRef]

106. Cherrington, N.J.; Cao, Y.; Cherrington, J.W.; Rose, R.L.; Hodgson, E. Physiological factors affecting protein expression of flavin-containing monooxygenases 1,3 and 5. Xenobiotica 1998, 28, 673-682. [CrossRef]

107. Bennett, B.J.; de Aguiar Vallim, T.Q.; Wang, Z.; Shih, D.M.; Meng, Y.; Gregory, J.; Allayee, H.; Lee, R.; Graham, M.; Crooke, R.; et al. Trimethylamine- $N$-oxide, a metabolite associated with atherosclerosis, exhibits complex genetic and dietary regulation. Cell Metab. 2013, 17, 49-60. [CrossRef] [PubMed]

108. Lattard, V.; Lachuer, J.; Buronfosse, T.; Garnier, F.; Benoit, E. Physiological factors affecting the expression of FMO1 and FMO3 in the rat liver and kidney. Biochem. Pharmacol. 2002, 63, 1453-1464. [CrossRef]

109. Jezek, P.; Jaburek, M.; Plecita-Hlavata, L. Contribution of Oxidative Stress and Impaired Biogenesis of Pancreatic $\beta$-Cells to Type 2 Diabetes. Antioxid. Redox Signal. 2019, 31, 722-751. [CrossRef]

110. Achard, C.S.; Laybutt, D.R. Lipid-induced endoplasmic reticulum stress in liver cells results in two distinct outcomes: Adaptation with enhanced insulin signaling or insulin resistance. Endocrinology 2012, 153, 2164-2177. [CrossRef]

111. Igoillo-Esteve, M.; Marselli, L.; Cunha, D.A.; Ladriere, L.; Ortis, F.; Grieco, F.A.; Dotta, F.; Weir, G.C.; Marchetti, P.; Eizirik, D.L.; et al. Erratum to: Palmitate induces a pro-inflammatory response in human pancreatic islets that mimics CCL2 expression by beta cells in type 2 diabetes. Diabetologia 2012, 55, 863. [CrossRef]

112. Touyz, R.M.; Rios, F.J.; Alves-Lopes, R.; Neves, K.B.; Camargo, L.L.; Montezano, A.C. Oxidative Stress: A Unifying Paradigm in Hypertension. Can. J. Cardiol. 2020, 36, 659-670. [CrossRef] [PubMed]

113. Lin, N.; Chen, H.; Zhang, H.; Wan, X.; Su, Q. Mitochondrial reactive oxygen species (ROS) inhibition ameliorates palmitateinduced INS-1 beta cell death. Endocrine 2012, 42, 107-117. [CrossRef] 
114. Lin, N.; Zhang, H.; Su, Q. Advanced glycation end-products induce injury to pancreatic beta cells through oxidative stress. Diabetes Metab. 2012, 38, 250-257. [CrossRef]

115. Rocha, M.; Diaz-Morales, N.; Rovira-Llopis, S.; Escribano-Lopez, I.; Banuls, C.; Hernandez-Mijares, A.; Diamanti-Kandarakis, E.; Victor, V.M. Mitochondrial Dysfunction and Endoplasmic Reticulum Stress in Diabetes. Curr. Pharm. Des. 2016, 22, $2640-2649$. [CrossRef]

116. Ozcan, U.; Yilmaz, E.; Ozcan, L.; Furuhashi, M.; Vaillancourt, E.; Smith, R.O.; Gorgun, C.Z.; Hotamisligil, G.S. Chemical chaperones reduce ER stress and restore glucose homeostasis in a mouse model of type 2 diabetes. Science 2006, 313, 1137-1140. [CrossRef]

117. Sigfrid, L.A.; Cunningham, J.M.; Beeharry, N.; Hakan Borg, L.A.; Rosales Hernandez, A.L.; Carlsson, C.; Bone, A.J.; Green, I.C. Antioxidant enzyme activity and mRNA expression in the islets of Langerhans from the BB/S rat model of type 1 diabetes and an insulin-producing cell line. J. Mol. Med. 2004, 82, 325-335. [CrossRef] [PubMed]

118. Grankvist, K.; Marklund, S.L.; Taljedal, I.B. CuZn-superoxide dismutase, Mn-superoxide dismutase, catalase and glutathione peroxidase in pancreatic islets and other tissues in the mouse. Biochem. J. 1981, 199, 393-398. [CrossRef]

119. Unger, R.H.; Grundy, S. Hyperglycaemia as an inducer as well as a consequence of impaired islet cell function and insulin resistance: Implications for the management of diabetes. Diabetologia 1985, 28, 119-121. [CrossRef]

120. Kleinfeld, A.M.; Prothro, D.; Brown, D.L.; Davis, R.C.; Richieri, G.V.; DeMaria, A. Increases in serum unbound free fatty acid levels following coronary angioplasty. Am. J. Cardiol. 1996, 78, 1350-1354. [CrossRef]

121. Akerfeldt, M.C.; Howes, J.; Chan, J.Y.; Stevens, V.A.; Boubenna, N.; McGuire, H.M.; King, C.; Biden, T.J.; Laybutt, D.R. Cytokineinduced $\beta$-cell death is independent of endoplasmic reticulum stress signaling. Diabetes 2008, 57, 3034-3044. [CrossRef] [PubMed]

122. Vela-Guajardo, J.E.; Garza-Gonzalez, S.; Garcia, N. Glucolipotoxicity-induced Oxidative Stress is Related to Mitochondrial Dysfunction and Apoptosis of Pancreatic $\beta$-cell. Curr. Diabetes Rev. 2021, 17, e031120187541. [CrossRef]

123. Wang, H.; Kouri, G.; Wollheim, C.B. ER stress and SREBP-1 activation are implicated in $\beta$-cell glucolipotoxicity. J. Cell Sci. 2005, 118, 3905-3915. [CrossRef] [PubMed]

124. Hasnain, S.Z.; Prins, J.B.; McGuckin, M.A. Oxidative and endoplasmic reticulum stress in $\beta$-cell dysfunction in diabetes. J. Mol. Endocrinol. 2016, 56, R33-R54. [CrossRef]

125. Oslowski, C.M.; Urano, F. A switch from life to death in endoplasmic reticulum stressed $\beta$-cells. Diabetes Obes. Metab. 2010, 12 (Suppl. 2), 58-65. [CrossRef]

126. Scheuner, D.; Kaufman, R.J. The unfolded protein response: A pathway that links insulin demand with $\beta$-cell failure and diabetes. Endocr. Rev. 2008, 29, 317-333. [CrossRef]

127. Somesh, B.P.; Verma, M.K.; Sadasivuni, M.K.; Mammen-Oommen, A.; Biswas, S.; Shilpa, P.C.; Reddy, A.K.; Yateesh, A.N.; Pallavi, P.M.; Nethra, S.; et al. Chronic glucolipotoxic conditions in pancreatic islets impair insulin secretion due to dysregulated calcium dynamics, glucose responsiveness and mitochondrial activity. BMC Cell Biol. 2013, 14, 31. [CrossRef] [PubMed]

128. Marsh, B.J.; Mastronarde, D.N.; Buttle, K.F.; Howell, K.E.; McIntosh, J.R. Organellar relationships in the Golgi region of the pancreatic beta cell line, HIT-T15, visualized by high resolution electron tomography. Proc. Natl. Acad. Sci. USA 2001, 98, 2399-2406. [CrossRef]

129. Steiner, D.F. The proprotein convertases. Curr. Opin. Chem. Biol. 1998, 2, 31-39. [CrossRef]

130. Davidson, H.W. (Pro)Insulin processing: A historical perspective. Cell Biochem. Biophys. 2004, 40, 143-158. [CrossRef] [PubMed]

131. Davidson, H.W.; Rhodes, C.J.; Hutton, J.C. Intraorganellar calcium and $\mathrm{pH}$ control proinsulin cleavage in the pancreatic $\beta$ cell via two distinct site-specific endopeptidases. Nature 1988, 333, 93-96. [CrossRef]

132. Wang, J.; Yang, X.; Zhang, J. Bridges between mitochondrial oxidative stress, ER stress and mTOR signaling in pancreatic $\beta$ cells. Cell. Signal. 2016, 28, 1099-1104. [CrossRef]

133. Hotamisligil, G.S. Endoplasmic reticulum stress and the inflammatory basis of metabolic disease. Cell 2010, 140, 900-917. [CrossRef]

134. Bertolotti, A.; Zhang, Y.; Hendershot, L.M.; Harding, H.P.; Ron, D. Dynamic interaction of BiP and ER stress transducers in the unfolded-protein response. Nat. Cell Biol. 2000, 2, 326-332. [CrossRef] [PubMed]

135. Huang, C.J.; Haataja, L.; Gurlo, T.; Butler, A.E.; Wu, X.; Soeller, W.C.; Butler, P.C. Induction of endoplasmic reticulum stressinduced $\beta$-cell apoptosis and accumulation of polyubiquitinated proteins by human islet amyloid polypeptide. Am. J. Physiol. Endocrinol. Metab. 2007, 293, E1656-E1662. [CrossRef]

136. Pirot, P.; Naamane, N.; Libert, F.; Magnusson, N.E.; Orntoft, T.F.; Cardozo, A.K.; Eizirik, D.L. Global profiling of genes modified by endoplasmic reticulum stress in pancreatic beta cells reveals the early degradation of insulin mRNAs. Diabetologia 2007, 50, 1006-1014. [CrossRef] [PubMed]

137. Yusta, B.; Baggio, L.L.; Estall, J.L.; Koehler, J.A.; Holland, D.P.; Li, H.; Pipeleers, D.; Ling, Z.; Drucker, D.J. GLP-1 receptor activation improves $\beta$ cell function and survival following induction of endoplasmic reticulum stress. Cell Metab. 2006, 4, 391-406. [CrossRef] [PubMed]

138. Eizirik, D.L.; Cnop, M. ER stress in pancreatic $\beta$ cells: The thin red line between adaptation and failure. Sci. Signal. 2010,3 , pe7. [CrossRef]

139. Cunha, D.A.; Hekerman, P.; Ladriere, L.; Bazarra-Castro, A.; Ortis, F.; Wakeham, M.C.; Moore, F.; Rasschaert, J.; Cardozo, A.K.; Bellomo, E.; et al. Initiation and execution of lipotoxic ER stress in pancreatic $\beta$-cells. J. Cell Sci. 2008, 121, 2308-2318. [CrossRef] [PubMed] 
140. Oyadomari, S.; Mori, M. Roles of CHOP/GADD153 in endoplasmic reticulum stress. Cell Death Differ. 2004, 11, 381-389. [CrossRef] [PubMed]

141. Qiu, Y.; Mao, T.; Zhang, Y.; Shao, M.; You, J.; Ding, Q.; Chen, Y.; Wu, D.; Xie, D.; Lin, X.; et al. A crucial role for RACK1 in the regulation of glucose-stimulated IRE1 $\alpha$ activation in pancreatic $\beta$ cells. Sci. Signal. 2010, 3, ra7. [CrossRef] [PubMed]

142. Ozcan, U.; Cao, Q.; Yilmaz, E.; Lee, A.H.; Iwakoshi, N.N.; Ozdelen, E.; Tuncman, G.; Gorgun, C.; Glimcher, L.H.; Hotamisligil, G.S. Endoplasmic reticulum stress links obesity, insulin action, and type 2 diabetes. Science 2004, 306, 457-461. [CrossRef]

143. Ogata, M.; Hino, S.; Saito, A.; Morikawa, K.; Kondo, S.; Kanemoto, S.; Murakami, T.; Taniguchi, M.; Tanii, I.; Yoshinaga, K.; et al. Autophagy is activated for cell survival after endoplasmic reticulum stress. Mol. Cell. Biol. 2006, 26, 9220-9231. [CrossRef]

144. Ebato, C.; Uchida, T.; Arakawa, M.; Komatsu, M.; Ueno, T.; Komiya, K.; Azuma, K.; Hirose, T.; Tanaka, K.; Kominami, E.; et al. Autophagy is important in islet homeostasis and compensatory increase of beta cell mass in response to high-fat diet. Cell Metab. 2008, 8, 325-332. [CrossRef] [PubMed]

145. Jung, H.S.; Chung, K.W.; Won Kim, J.; Kim, J.; Komatsu, M.; Tanaka, K.; Nguyen, Y.H.; Kang, T.M.; Yoon, K.H.; Kim, J.W.; et al. Loss of autophagy diminishes pancreatic $\beta$ cell mass and function with resultant hyperglycemia. Cell Metab. 2008, 8, 318-324. [CrossRef] [PubMed]

146. Tsuchiya, Y.; Saito, M.; Kadokura, H.; Miyazaki, J.I.; Tashiro, F.; Imagawa, Y.; Iwawaki, T.; Kohno, K. IRE1-XBP1 pathway regulates oxidative proinsulin folding in pancreatic $\beta$ cells. J. Cell Biol. 2018, 217, 1287-1301. [CrossRef]

147. Parkin, K.L.; Hultin, H.O. Partial purification of trimethylamine-N-oxide (TMAO) demethylase from crude fish muscle microsomes by detergents. J. Biochem. 1986, 100, 87-97. [CrossRef]

148. Ganguly, P.; Boserman, P.; van der Vegt, N.F.A.; Shea, J.E. Trimethylamine N-oxide Counteracts Urea Denaturation by Inhibiting Protein-Urea Preferential Interaction. J. Am. Chem. Soc. 2018, 140, 483-492. [CrossRef] [PubMed]

149. Pincus, D.L.; Hyeon, C.; Thirumalai, D. Effects of trimethylamine N-oxide (TMAO) and crowding agents on the stability of RNA hairpins. J. Am. Chem. Soc. 2008, 130, 7364-7372. [CrossRef] [PubMed]

150. Arakawa, T.; Timasheff, S.N. The stabilization of proteins by osmolytes. Biophys. J. 1985, 47, 411-414. [CrossRef]

151. Mashino, T.; Fridovich, I. Effects of urea and trimethylamine-N-oxide on enzyme activity and stability. Arch. Biochem. Biophys. 1987, 258, 356-360. [CrossRef]

152. Hu, C.Y.; Lynch, G.C.; Kokubo, H.; Pettitt, B.M. Trimethylamine N-oxide influence on the backbone of proteins: An oligoglycine model. Proteins 2010, 78, 695-704. [CrossRef]

153. Bennion, B.J.; DeMarco, M.L.; Daggett, V. Preventing misfolding of the prion protein by trimethylamine $N$-oxide. Biochemistry 2004, 43, 12955-12963. [CrossRef] [PubMed]

154. Bennion, B.J.; Daggett, V. Counteraction of urea-induced protein denaturation by trimethylamine $N$-oxide: A chemical chaperone at atomic resolution. Proc. Natl. Acad. Sci. USA 2004, 101, 6433-6438. [CrossRef]

155. Mulhern, M.L.; Madson, C.J.; Kador, P.F.; Randazzo, J.; Shinohara, T. Cellular osmolytes reduce lens epithelial cell death and alleviate cataract formation in galactosemic rats. Mol. Vis. 2007, 13, 1397-1405. [PubMed]

156. Rezus, Y.L.; Bakker, H.J. Destabilization of the hydrogen-bond structure of water by the osmolyte trimethylamine $N$-oxide. J. Phys. Chem. B 2009, 113, 4038-4044. [CrossRef]

157. Yancey, P.H.; Siebenaller, J.F. Co-evolution of proteins and solutions: Protein adaptation versus cytoprotective micromolecules and their roles in marine organisms. J. Exp. Biol. 2015, 218, 1880-1896. [CrossRef] [PubMed]

158. Hong, J.; Xiong, S. TMAO-Protein Preferential Interaction Profile Determines TMAO's Conditional In Vivo Compatibility. Biophys. J. 2016, 111, 1866-1875. [CrossRef]

159. Govindarajulu, M.; Pinky, P.D.; Steinke, I.; Bloemer, J.; Ramesh, S.; Kariharan, T.; Rella, R.T.; Bhattacharya, S.; Dhanasekaran, M.; Suppiramaniam, V.; et al. Gut Metabolite TMAO Induces Synaptic Plasticity Deficits by Promoting Endoplasmic Reticulum Stress. Front. Mol. Neurosci. 2020, 13, 138. [CrossRef] [PubMed]

160. Gao, X.; Liu, X.; Xu, J.; Xue, C.; Xue, Y.; Wang, Y. Dietary trimethylamine $N$-oxide exacerbates impaired glucose tolerance in mice fed a high fat diet. J. Biosci. Bioeng. 2014, 118, 476-481. [CrossRef]

161. Gao, X.; Xu, J.; Jiang, C.; Zhang, Y.; Xue, Y.; Li, Z.; Wang, J.; Xue, C.; Wang, Y. Fish oil ameliorates trimethylamine N-oxideexacerbated glucose intolerance in high-fat diet-fed mice. Food Funct. 2015, 6, 1117-1125. [CrossRef]

162. Mari, A. Mathematical modeling in glucose metabolism and insulin secretion. Curr. Opin. Clin. Nutr. Metab. Care 2002, 5, 495-501. [CrossRef] [PubMed]

163. Kim, M.; Oh, T.J.; Lee, J.C.; Choi, K.; Kim, M.Y.; Kim, H.C.; Cho, Y.M.; Kim, S. Simulation of oral glucose tolerance tests and the corresponding isoglycemic intravenous glucose infusion studies for calculation of the incretin effect. J. Korean Med. Sci. 2014, 29, 378-385. [CrossRef] [PubMed]

164. Michalowska, J.; Miller-Kasprzak, E.; Bogdanski, P. Incretin Hormones in Obesity and Related Cardiometabolic Disorders: The Clinical Perspective. Nutrients 2021, 13, 351. [CrossRef] [PubMed]

165. Creutzfeldt, W. The incretin concept today. Diabetologia 1979, 16, 75-85. [CrossRef]

166. Creutzfeldt, W.; Ebert, R. New developments in the incretin concept. Diabetologia 1985, 28, 565-573. [CrossRef]

167. Meier, J.J.; Nauck, M.A. Glucagon-like peptide 1(GLP-1) in biology and pathology. Diabetes Metab. Res. Rev. 2005, 21, 91-117. [CrossRef]

168. Drucker, D.J.; Nauck, M.A. The incretin system: Glucagon-like peptide-1 receptor agonists and dipeptidyl peptidase-4 inhibitors in type 2 diabetes. Lancet 2006, 368, 1696-1705. [CrossRef] 
169. Bergman, R.N.; Phillips, L.S.; Cobelli, C. Physiologic evaluation of factors controlling glucose tolerance in man: Measurement of insulin sensitivity and beta-cell glucose sensitivity from the response to intravenous glucose. J. Clin. Investig. 1981, 68, $1456-1467$. [CrossRef]

170. Dumas, M.E.; Rothwell, A.R.; Hoyles, L.; Aranias, T.; Chilloux, J.; Calderari, S.; Noll, E.M.; Pean, N.; Boulange, C.L.; Blancher, C.; et al. Microbial-Host Co-metabolites Are Prodromal Markers Predicting Phenotypic Heterogeneity in Behavior, Obesity, and Impaired Glucose Tolerance. Cell Rep. 2017, 20, 136-148. [CrossRef]

171. Liao, B.M.; McManus, S.A.; Hughes, W.E.; Schmitz-Peiffer, C. Flavin-Containing Monooxygenase 3 Reduces Endoplasmic Reticulum Stress in Lipid-Treated Hepatocytes. Mol. Endocrinol. 2016, 30, 417-428. [CrossRef]

172. Li, X.; Geng, J.; Zhao, J.; Ni, Q.; Zhao, C.; Zheng, Y.; Chen, X.; Wang, L. Trimethylamine N-Oxide Exacerbates Cardiac Fibrosis via Activating the NLRP3 Inflammasome. Front. Physiol. 2019, 10, 866. [CrossRef] [PubMed]

173. Ortiz-Costa, S.; Sorenson, M.M.; Sola-Penna, M. Counteracting effects of urea and methylamines in function and structure of skeletal muscle myosin. Arch. Biochem. Biophys. 2002, 408, 272-278. [CrossRef]

174. Warrier, M.; Shih, D.M.; Burrows, A.C.; Ferguson, D.; Gromovsky, A.D.; Brown, A.L.; Marshall, S.; McDaniel, A.; Schugar, R.C.; Wang, Z; et al. The TMAO-Generating Enzyme Flavin Monooxygenase 3 Is a Central Regulator of Cholesterol Balance. Cell Rep. 2015, 10, 326-338. [CrossRef] [PubMed]

175. Lupachyk, S.; Watcho, P.; Stavniichuk, R.; Shevalye, H.; Obrosova, I.G. Endoplasmic reticulum stress plays a key role in the pathogenesis of diabetic peripheral neuropathy. Diabetes 2013, 62, 944-952. [CrossRef]

176. Zhuang, R.; Ge, X.; Han, L.; Yu, P.; Gong, X.; Meng, Q.; Zhang, Y.; Fan, H.; Zheng, L.; Liu, Z.; et al. Gut microbe-generated metabolite trimethylamine $N$-oxide and the risk of diabetes: A systematic review and dose-response meta-analysis. Obes. Rev. 2019, 20, 883-894. [CrossRef]

177. Zhu, Y.; Li, Q.; Jiang, H. Gut microbiota in atherosclerosis: Focus on trimethylamine N-oxide. APMIS 2020, 128, 353-366. [CrossRef]

178. Zhu, W.; Wang, Z.; Tang, W.H.W.; Hazen, S.L. Gut Microbe-Generated Trimethylamine N-Oxide From Dietary Choline Is Prothrombotic in Subjects. Circulation 2017, 135, 1671-1673. [CrossRef]

179. Zhao, Y.; Wang, Z. Impact of trimethylamine N-oxide (TMAO) metaorganismal pathway on cardiovascular disease. J. Lab. Precis. Med. 2020, 5, 16. [CrossRef]

180. Janeiro, M.H.; Ramirez, M.J.; Milagro, F.I.; Martinez, J.A.; Solas, M. Implication of Trimethylamine N-Oxide (TMAO) in Disease: Potential Biomarker or New Therapeutic Target. Nutrients 2018, 10, 1398. [CrossRef] [PubMed]

181. Oakley, C.I.; Vallejo, J.A.; Wang, D.; Gray, M.A.; Tiede-Lewis, L.M.; Shawgo, T.; Daon, E.; Zorn, G., 3rd; Stubbs, J.R.; Wacker, M.J. Trimethylamine-N-oxide acutely increases cardiac muscle contractility. Am. J. Physiol. Heart Circ. Physiol. 2020, 318, H1272-H1282. [CrossRef] [PubMed]

182. Ufnal, M.; Nowinski, A. Is increased plasma TMAO a compensatory response to hydrostatic and osmotic stress in cardiovascular diseases? Med. Hypotheses 2019, 130, 109271. [CrossRef] [PubMed] 